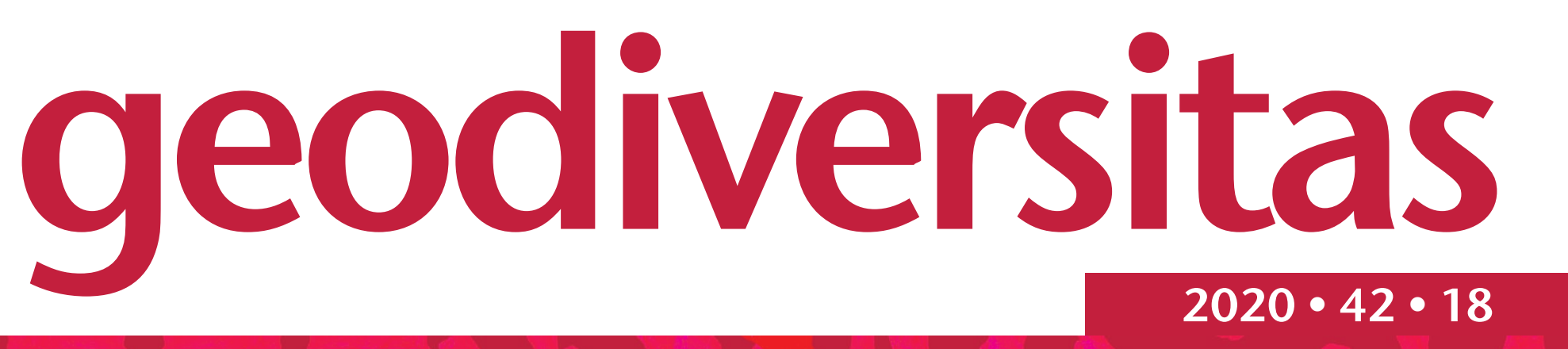

On the morphology of the astragalus and calcaneus of the amphicyonids (Carnivora, Mammalia) from the Paleogene of Europe: implications for the ecology of the European bear-dogs

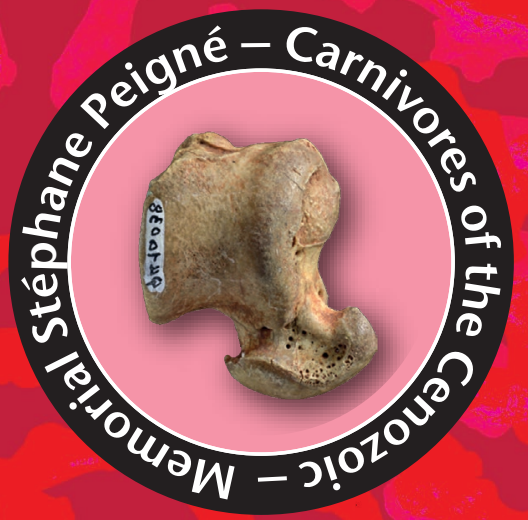

Morgane FOURNIER, Sandrine LADEVËZE, Kevin LE VERGER, Valentin FISCHER, Robert P. SPEIJER \& Floréal SOLÉ 
DiReCteur de LA PUblication / PUBLICATION DIRECTOR : Bruno David,

Président du Muséum national d'Histoire naturelle

RÉDACTEUR EN CHEF / EDITOR-IN-CHIEF: Didier Merle

ASSISTANTS DE RÉDACTION / ASSISTANT EDITORS : Emmanuel Côtez (geodiv@mnhn.fr)

Mise EN PAGE / PAGE LAYOUT: Emmanuel Côtez

COMITÉ SCIENTIFIQUE / SCIENTIFIC BOARD:

Christine Argot (Muséum national d'Histoire naturelle, Paris)

Beatrix Azanza (Museo Nacional de Ciencias Naturales, Madrid)

Raymond L. Bernor (Howard University, Washington DC)

Alain Blieck (chercheur CNRS retraité, Haubourdin)

Henning Blom (Uppsala University)

Jean Broutin (Sorbonne Université, Paris, retraité)

Gaël Clément (Muséum national d'Histoire naturelle, Paris)

Ted Daeschler (Academy of Natural Sciences, Philadelphie)

Bruno David (Muséum national d'Histoire naturelle, Paris)

Gregory D. Edgecombe (The Natural History Museum, Londres)

Ursula Göhlich (Natural History Museum Vienna)

Jin Meng (American Museum of Natural History, New York)

Brigitte Meyer-Berthaud (CIRAD, Montpellier)

Zhu Min (Chinese Academy of Sciences, Pékin)

Isabelle Rouget (Muséum national d'Histoire naturelle, Paris)

Sevket Sen (Muséum national d'Histoire naturelle, Paris, retraité)

Stanislav Štamberg (Museum of Eastern Bohemia, Hradec Králové)

Paul Taylor (The Natural History Museum, Londres, retraité)

COUVERTURE / COVER:

Réalisée à partir des Figures de l'article/Made from the Figures of the article.

Geodiversitas est indexé dans / Geodiversitas is indexed in:

- Science Citation Index Expanded (SciSearch ${ }^{\circledR}$ )

- ISI Alerting Services ${ }^{\circledR}$

- Current Contents ${ }^{\circledR}$ / Physical, Chemical, and Earth Sciences ${ }^{\circledR}$

- Scopus ${ }^{\circledR}$

Geodiversitas est distribué en version électronique par / Geodiversitas is distributed electronically by:

- BioOne ${ }^{\circledR}$ (http://www.bioone.org)

Les articles ainsi que les nouveautés nomenclaturales publiés dans Geodiversitas sont référencés par / Articles and nomenclatural novelties published in Geodiversitas are referenced by:

- ZooBank ${ }^{\circledR}$ (http://zoobank.org)

Geodiversitas est une revue en flux continu publiée par les Publications scientifiques du Muséum, Paris Geodiversitas is a fast track journal published by the Museum Science Press, Paris

Les Publications scientifiques du Muséum publient aussi / The Museum Science Press also publish:

Adansonia, Zoosystema, Anthropozoologica, European Journal of Taxonomy, Naturae, Cryptogamie sous-sections Algologie, Bryologie, Mycologie.

Diffusion - Publications scientifiques Muséum national d'Histoire naturelle

CP $41-57$ rue Cuvier F-75231 Paris cedex 05 (France)

Tél. : 33 (0)1407948 05 / Fax: 33 (0)14079 3840

diff.pub@mnhn.fr / http://sciencepress.mnhn.fr

(C) Publications scientifiques du Muséum national d'Histoire naturelle, Paris, 2020

ISSN (imprimé / print): 1280-9659/ ISSN (électronique / electronic): 1638-9395 


\section{On the morphology of the astragalus and calcaneus of the amphicyonids (Carnivora, Mammalia) from the Paleogene of Europe: implications for the ecology of the European bear-dogs}

Morgane FOURNIER
Sandrine LADEVĖZE
Kévin LE VERGER

CR2P (CNRS, MNHN, Sorbonne Université), Département Origines et Évolution, Muséum national d'Histoire naturelle, case postale 38, 57 rue Cuvier, F-75231 Paris cedex 05 (France)

Valentin FISCHER

Evolution \& Diversity Dynamics Lab, Université de Liège (ULiège), Quartier Agora, Bâtiment B18, Allée du six août, 14, 4000 Liège (Belgium)

Robert P. SPEIJER

KU Leuven, Department of Earth and Environmental Sciences, Celestijnenlaan 200E, B-3001 Leuven-Heverlee (Belgium)

Floréal SOLÉ

Directorate Earth and History of Life, Palaeobiosphere Evolution Research Unit, Royal Belgian Institute of Natural Sciences, Rue Vautier 29, B-1000 Brussels (Belgium)

Submitted on 1 January 2019 | accepted on 13 March 2020 | published on 16 July 2020

urn:Isid:zoobank.org:pub:030C3660-4FC5-4C68-BD56-226860C8FD1C

Fournier M., Ladevèze S., Le Verger K., Fischer V., Speijer R. P.\& Solé F. 2020. - On the morphology of the astragalus and calcaneus of the amphicyonids (Carnivora, Mammalia) from the Paleogene of Europe: implications for the ecology of the European bear-dogs, in Bonis L. de \& Werdelin L. (eds), Memorial to Stéphane Peigné: Carnivores (Hyaenodonta and Carnivora) of the Cenozoic. Geodiversitas 42 (18): 305-325. https://doi.org/10.5252/geodiversitas2020v42a18. http://geodiversitas.com/42/18

\section{ABSTRACT}

The Paleogene mammals of Europe are rarely known from partial or complete skeletons. As a result, their systematics and ecology are often solely based on dental characters and postcranial remains, when available, are usually neglected. This explains why the locomotion of mammals of the EoceneOligocene transition, the "Grande Coupure", is poorly known. The aim of this study is to describe the tarsal bones (astragali and calcanei) and characterize the locomotion of amphicyonid carnivorans, one of the most abundant mammalian predator groups from the Phosphorites du Quercy (France) sites. The identification of taxa and the characterization of both posture and locomotion were car-

KEY WORDS

Caniformia,

Quercy,

France,

Eocene,

Oligocene,

Diet,

Posture, ried out using four criteria: relative abundance (in comparison with dental data), morphology, size, and body mass. Seven morphotypes, four among astragali and three among calcanei, are identified as Amphicyonidae and show various postures: plantigrade, semi-digitigrade, and digitigrade. One morphotype of the astragalus and one of the calcaneus are identified as Cynodictis lacustris Gervais, 1852, which exhibits a digitigrade posture. The study of postcranial bones, such as tarsals, allows for a better understanding of the ecology of these animals and deserves more interest in future morphological and phylogenetic studies. 


MOTS CLÉS
Caniformia,
Quercy,
France,
Éocène,
Oligocène,
régime alimentaire,
posture,
locomotion.

\begin{abstract}
RÉSUMÉ
À propos de la morphologie de l'astragale et du calcanéum des amphicyonidés (Carnivora, Mammalia) du Paléogène d'Europe; implications sur l'écologie des chiens-ours européens.

Les mammiferes du Paléogène Européen sont rarement représentés par des squelettes complets et leur systématique est souvent fondée sur des caractères dentaires. Le squelette postcrânien est, en comparaison, délaissé car très fragmentaire, ce qui rend son attribution systématique difficile, voire impossible de prime abord. Cela explique, en particulier, pourquoi la locomotion des faunes mammaliennes de la transition Éocène-Oligocène, nommée "Grande Coupure», est extrêmement peu connue. Le but de cette étude est de décrire et caractériser la locomotion de l'un des plus abondants groupes de prédateurs mammaliens des Phosphorites du Quercy (France), les carnivores amphicyonidés. Le matériel étudié est composé de deux os du tarse, l'astragale et le calcanéum, qui jouent un rôle important dans le mouvement du pied. L'identification des taxons et la caractérisation de la posture et de la locomotion se font selon quatre critères: abondance relative, morphologie, taille et masse corporelle. Sept morphotypes - quatre pour les astragales et trois pour les calcanéums - sont identifiés comme Amphicyonidae; ils montrent différentes postures : plantigrade, semi-digitigrade et digitigrade. Deux d'entre eux sont identifiés comme appartenant à Cynodictis lacustris Gervais, 1852; ils présentent une posture digitigrade. L'étude des os postcrâniens permet, au final, de mieux comprendre l'écologie de ces animaux et mérite assurément plus d'attention dans les études ultérieures.
\end{abstract}

\section{INTRODUCTION}

The "Grande Coupure" is one of the main events that impacted the evolution of European Paleogene mammals (Legendre \& Hartenberger 1992). First described by Stehlin (1910), this event corresponds to the transition between the Eocene and the Oligocene in Europe ( \pm 33.9 Ma; Vandenberghe et al. 2012). It is characterized by an important decrease in global temperature (Zachos et al. 2008), which would have led to the decline of forests that were predominant in the middle Eocene, and resulted in a transition from a rather hot and humid climate to an arid climate (Legendre 1989; Legendre et al. 1991; Escarguel et al. 2008). These environmental changes, as well as the migration of many mammals from Asia, were probably the main drivers of the profound modifications seen in the European fauna with disappearances within several mammal groups and, conversely, diversification in others (Legendre \& Hartenberger 1992).

This faunal turnover is particularly noticeable among carnivorous mammals. Hyaenodonta - an extinct group distributed across Laurasia and Africa - were abundant and diverse during the Eocene in Europe (from 56 to $33.9 \mathrm{Ma}$; Solé et al. 2014, 2015) and declined rapidly during the Oligocene (from 33.9 to $23.03 \mathrm{Ma}$ ) (Legendre \& Hartenberger 1992). Conversely, the diversity of Carnivora exploded after the Grande Coupure (Legendre et al. 1991), resulting in the appearance of various clades of feliformians (e.g., Nimravidae) and caniformians (e.g., Amphicyonidae, Ursoidea, Ailuridae, Musteloidea) (Goswami \& Friscia 2010). Carnivora is one of the most diverse placental orders currently recognized, with 281 species (Wilson \& Mittermeier 2009).

The Quercy region (southwestern France; Fig. 1) contains many deposits that are crucial to a better understanding of this faunal turnover, with more than 80 distinct mammal faunas, all associated to karstic fissure fillings (Legendre et al. 1997). These paleokarst faunas range from the middle Eocene (c. $38 \mathrm{Ma}$ ) to the early Miocene (c. $22 \mathrm{Ma}$ ) (Renault et al. 1978; Remy et al. 1987; Maitre et al. 2006; Escarguel et al. 2008; Maitre 2014), and include various clades: Marsupialia, Primates, Chiroptera, Rodentia, Artiodactyla, Perissodactyla, and Carnivora (Legendre 1989; Legendre et al. 1991; Maitre 2014). The extensive temporal record of these faunas, in addition to the quality and richness of the mammal fossils, makes the Quercy region one of the most important for understanding the evolution of European Paleogene mammals (Legendre \& Hartenberger 1992; Escarguel et al. 2008). However, from the beginning of the exploitation of the Quercy Phosphorites in the late 1860's until the mid-20th century, the exact sources of the fossils were rarely recorded, and only toponyms were provided (e.g., Caylux, Lamandine, Bach). These localities do not correspond to clearly defined fossiliferous sites but to nearby villages, resulting in occasional mixing of faunas of different ages (Maitre 2014; Pélissié 2015). The fossils collected during that period make up the so-called "old collections" (Rage 2006). However, since 1965, paleontologists have more precisely exploited the rich fissure fillings of this area in order to provide a refined chronology of the deposits (Bonis et al. 1973; Remy et al. 1987; BiochroM'97 1997a). This has enabled characterisation of the long-term evolution of the regional mammal fauna (Escarguel \& Legendre 2006; Escarguel et al. 2008).

In the Quercy Phosphorites, dental remains are generally well preserved and are preferentially used for taxonomic identifications. Furthermore, dental remains provide information on diet, as well as body mass (e.g., Coillot et al. 2013). Postcranial remains are rarely found in association 


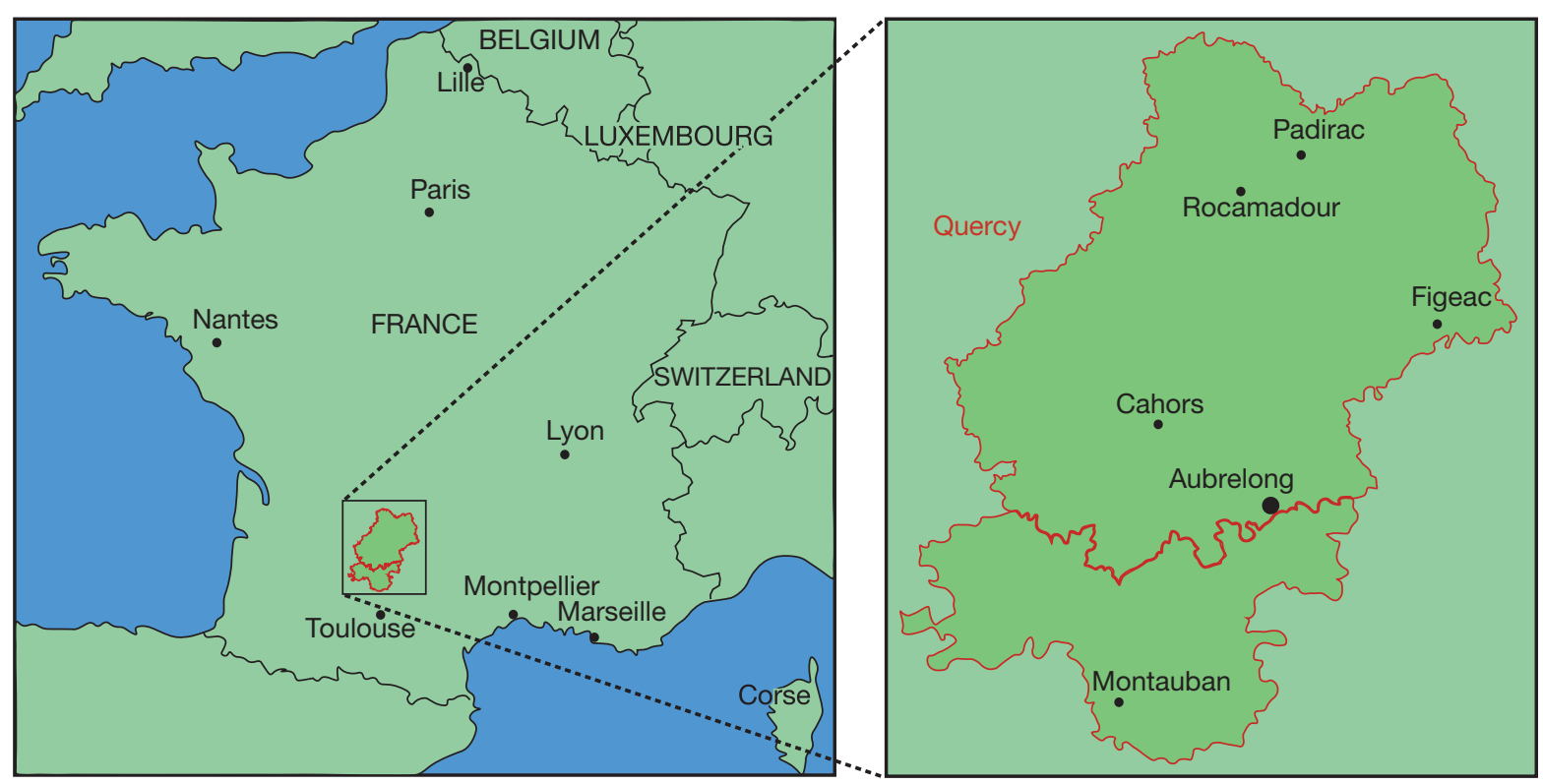

FIG. 1. - Location map of Aubrelong (France; Rupelian, MP21) where the new fossils of Cynodictis lacustris were found. The Quercy area is composed of the Lot Department and part of the Tarn-et-Garonne.

with dental remains, and are difficult to associate with certainty to craniodental elements; consequently they have often been neglected. For instance, the predator taxa known from the Quercy Phosphorites were mostly defined on the basis of dental characters, and the postcranial material associated with these taxa is extremely rare (e.g., Peigné 2000; Peigné \& Bonis 1999; Bonis 2011). Postcranial bones and dental elements were, however, not subjected to the same selective pressure (see Szalay \& Lucas (1996), and, as a result, two taxa can display widely different dental morphotypes but similar locomotor adaptations. The morphology of the postcranial bones of carnivorans are correlated with the type of locomotion, being influenced by habitat (arboreal or terrestrial) and/or by hunting strategies (pursuit or ambush) (Goswami \& Friscia 2010). This is particularly the case for the ankle bones and more particularly for astragali and calcanei. Their morphology is strongly correlated with the degree of flexion and inversion-eversion of the foot and thus provides information on the mechanics of the hindlimb (Panciroli et al. 2017). Therefore, postcranial material is the best indicator of locomotor and postural habits, which are an essential component for the reconstruction of the ecology (Panciroli et al. 2017).

The present study focuses on Amphicyonidae, which are among the most abundant carnivorous mammals in the Quercy deposits (Teilhard de Chardin 1915). They are therefore a key taxon to better understand the Grande Coupure and the evolution of Paleogene faunas. This family of Carnivora, the so-called 'bear-dogs', consists of at least 42 genera and ranges from the Eocene to the Miocene (Goswami \& Friscia 2010). The phylogenetic position of Amphicyonidae has long been debated: they were first considered closely related to Canidae (Matthew \& Granger 1924; Petter 1966), then placed as the sister group of Ursoidea (Ginsburg 1966;
Hough 1948; Hunt 1977; Wyss \& Flynn 1993), and more recently as the sister group of Arctoidea (Finarelli 2008; Hunt 1996, 1998), to finally be considered as the sister group of all Caniformia (Tomiya \& Tseng 2016).

This study aims to identify isolated ankle bones of Amphicyonidae as accurately as possible, using four criteria: relative abundance, size, body mass, and morphology. The final goal is to characterize the evolution of posture and locomotion of European amphicyonids across the "Grande Coupure" in order to reveal a new aspect of this profound turnover.

\section{MATERIAL AND METHODS}

\section{STUDIED SPECIMENS}

The study material includes 118 tarsal bones: 30 astragali and 88 calcanei; 61 of these fossils come from the Paleontology Collections of the Muséum national d'Histoire naturelle (MNHN, Paris), 28 belong to those of the Université de Liège (ULiege, Belgium) and 29 belong to those of the KU Leuven (KUL, Belgium). These bones are all from the Quercy Phosphorites (southwestern France). Of these, 91 lack locality information or have information that is of no use because it corresponds to undated localities from the Quercy area such as Caylus, Mouillac, Promilhanes, and Bach. The samples were identified in the three collections as "Carnivores" (i.e., Carnivora or Hyaenodonta) without further specification. Only 27 fossils are from a dated locality: Aubrelong (commune de Bach, Lot, France; Oligocene, Rupelian) (Fig. 1); this locality is close to the MP21 reference locality (Soumailles, France) of the MP scale (Gèze 1974; BiochroM'97 1997b; Lange-Badré 1970, $1979-\mathrm{MP}$ = Mammal Paleogene reference-levels BiochroM'97 1997b). 
TABLE 1. - List of specimens used for the comparisons.

\begin{tabular}{|c|c|c|}
\hline Family rank & Genus/species & References \\
\hline Hyaenodontidae & $\begin{array}{l}\text { Hyaenodon Laizer \& Parieu, } 1838 \\
\text { Galecyon chronius Zack, } 2011 \\
\text { Indohyaenodon raoi Bajpai, Kapur \& Thewissen, } 2009\end{array}$ & $\begin{array}{l}\text { Bastl } 2012 \\
\text { Zack \& Rose } 2015 \\
\text { Rana et al. } 2015\end{array}$ \\
\hline Nimravidae & $\begin{array}{l}\text { Hoplophoneus primaevus (Leidy \& Owen, 1851) } \\
\text { Nimravus brachyops (Cope, 1878) }\end{array}$ & $\begin{array}{l}\text { Barrett } 2016 \\
\text { Barrett } 2016\end{array}$ \\
\hline Miacidae & Vulpavus Marsh, 1871 & Heinrich \& Rose 1997 \\
\hline Ursidae & $\begin{array}{l}\text { Ursus spelaeus Rosenmüller, } 1794 \\
\text { Ursus arctos Linnaeus, } 1758\end{array}$ & $\begin{array}{l}\text { Santi et al. } 2005 \\
\text { Baryshnikov } 2015\end{array}$ \\
\hline Ailuridae & Simocyon batalleri (Viret, 1929) & Salesa et al. 2008 \\
\hline Mustelidae & $\begin{array}{l}\text { Martes sansaniensis Lartet, } 1851 \\
\text { Ischyrictis zibethoides Blainville, } 1841 \\
\text { Taxodon sansaniensis Lartet, } 1851\end{array}$ & $\begin{array}{l}\text { Peigné } 2012 \\
\text { Peigné } 2012 \\
\text { Peigné } 2012\end{array}$ \\
\hline Amphicyonidae & $\begin{array}{l}\text { Afrocyon ginsburgi Morales, Pickford, Soria \& Fraile, } 1998 \\
\text { Amphicyon major Blainville, } 1841 \\
\text { Amphicyon galushai Hunt, } 2003 \\
\text { Amphicyon lathanicus Ginsburg, Cheneval, Janvier, Pouit \& Sen, } 2000 \\
\text { Amphicyon giganteus Schinz, } 1825 \\
\text { Daphoenodon robustum Peterson, } 1910 \\
\text { Cynelos lemanensis Pomel, } 1846 \\
\text { Daphoenodon superbus Peterson, } 1907 \\
\text { Ysengrinia americana Wortman, } 1901\end{array}$ & $\begin{array}{l}\text { Morales et al. } 2016 \\
\text { Argot } 2010 \\
\text { Hunt } 2009 \\
\text { Ginsburg } 2002 \\
\text { Gagnaison et al. } 2017 \\
\text { Hunt } 2009 \\
\text { Peigné \& Heizmann } 2003 \\
\text { Hunt } 2011 \\
\text { Hunt } 2002\end{array}$ \\
\hline
\end{tabular}

TABLE 2. - Relative abundances (\%) of taxa defined on dental specimens, astragali and calcanei according to each collection (ULg, KUL and MNHN). Highlighted in gray, the values discussed in the text. Abbreviation: $\mathbf{n}$, number of specimens in the collections.

\begin{tabular}{|c|c|c|c|c|c|c|c|c|c|c|c|}
\hline \multirow[b]{2}{*}{ Taxa } & \multicolumn{3}{|c|}{ m1 } & \multicolumn{4}{|c|}{ Astragali } & \multicolumn{4}{|c|}{ Calcanei } \\
\hline & $\begin{array}{c}\text { Ulg } \\
(n=203)\end{array}$ & $\begin{array}{c}\text { KUL } \\
(n=58)\end{array}$ & $\begin{array}{c}\text { Total } \\
(n=261)\end{array}$ & $\begin{array}{c}\text { Ulg } \\
(n=15)\end{array}$ & $\begin{array}{c}\text { KUL } \\
(n=14)\end{array}$ & $\begin{array}{l}\text { MNHN } \\
(n=54)\end{array}$ & $\begin{array}{c}\text { Total } \\
(n=83)\end{array}$ & $\underset{(n=43)}{\text { Ulg }}$ & $\begin{array}{c}\text { KUL } \\
(n=36)\end{array}$ & $\begin{array}{c}\text { MNHN } \\
(n=85)\end{array}$ & $\begin{array}{c}\text { Total } \\
(n=164)\end{array}$ \\
\hline Hyaenodonta & 20 & - & 10 & 20 & 14.29 & 31.48 & 21.92 & 16.28 & 22.22 & 17.65 & 18.72 \\
\hline Miacidae & - & - & - & 6.67 & - & 5.55 & 4.07 & 13.95 & 5.56 & 7.06 & 8.86 \\
\hline Basal Aleuroidea & 19.02 & 27.59 & 23.31 & - & - & - & - & - & - & - & - \\
\hline Amphicyonidae & 30.73 & 31.03 & 30.88 & 20 & 57.14 & 35.19 & 42.21 & 58.14 & 58.33 & 49.41 & 55.28 \\
\hline Ursoidea & 16.59 & 39.66 & 28.12 & - & - & - & - & - & 8.33 & 11.76 & 6.7 \\
\hline Musteloidea & - & - & - & 40 & - & 9.25 & 16.42 & 2.33 & - & 2.35 & 1.56 \\
\hline Basal Arctoidea & 3.9 & 1.72 & 2.81 & - & - & - & - & - & - & - & - \\
\hline Ailuridae & 1.46 & - & 0.73 & - & - & - & - & - & - & - & - \\
\hline Caniformia indet & - & - & - & - & 14.29 & - & - & 4.65 & 5.55 & - & 3.4 \\
\hline Nimravidae & 8.29 & - & 4.145 & 13.3 & 14.29 & 16.67 & 14.76 & 2.33 & - & 8.24 & 3.52 \\
\hline Feliformia indet & - & - & - & - & - & 1.85 & 0.62 & 2.33 & - & 3.53 & 1.95 \\
\hline
\end{tabular}

\section{SYSTEMATIC IDENTIFICATION}

Due to the absence of identified carnivoran postcranial elements in the Quercy deposits and the fact that postcranial remains are found isolated from cranial elements, four criteria are used for the identification: morphology, relative abundance, size, and body mass. Postcranial elements of fossil Carnivora from other deposits in France, Eurasia, and North America, as well as extant, closely related species of Carnivora (Table 1), are used for the anatomical comparisons. Our analyses allowed us to identify as accurately as possible the tarsal bones studied (here at the family rank, Amphicyonidae). Due to their substantial postcranial morphological disparity (e.g., Argot 2010; Hunt 2009), Amphicyonidae are not formally characterized by discriminating features from the tarsal bones. We compensate for this by relying heavily on existing anatomical comparisons between Amphicyonidae and other extinct and extant carnivorans (Ginsburg 2002; Peigné \& Heizmann 2003; Argot 2010; Hunt 2002, 2009, 2011; Morales et al. 2016; Gagnaison et al. 2017), from which we were able to deduce general characteristics for each amphicyonid tarsal bone. These are the following: the astragalus displays a medial projection of the head and an asymmetrical trochlea, while the calcaneus has a rounded sustentacular facet and a cuboid facet with a slight tilt in a medioproximal-laterodistal orientation. These feature associations, however, may vary according to the amphicyonid species; for instance Daphoenodon robustum (Hunt 2009) and Amphicyon major (Argot 2010) display clearly different morphologies.

The relative abundances of the tarsal bones identified were compared to the dental specimens from the ULiege 
and KUL collections; these specimens were identified by F.S. and K.L.V. We chose to restrict our comparisons to these two Belgian collections because they have an unusually high abundance of dental and postcranial fossils and, unlike the MNHN, they seem to cover a short period of time, which implies a certain homogeneity (Solé et al. in press). The relative abundances are based on the number of specimens (dental material, astragalus, and calcaneus) of each group compared to the total number of specimens in the collection (Table 2).

Size and body mass can make it possible to further specify the identification at the species rank. Body masses of Amphicyonidae were estimated on the basis of dental material using the methods established by Van Valkenburgh (1990) for Carnivoramorpha (Table 3). The masses are calculated according to the following formula: $\log 10(B M)=[2.97 \times \log 10(\operatorname{Lm} 1)]-2.27 ; B M=$ estimated body mass in $\mathrm{kg}$; $\mathrm{Lm} 1$ = length of the first lower molar in millimeters. We also estimated the body mass of the taxa represented in our sample of tarsal bones. Body mass was estimated using the astragalus based on Tsubamoto (2014): $\log (B M)=[3.125 \times \log 10(\mathrm{La})]-0.463$; $\mathrm{BM}=$ estimated body mass in $\mathrm{g} ; \mathrm{La}=$ maximum length of the astragalus in millimeters (Table 4). Estimations are not yet possible from calcanei.

We use the terminology of recent works about the postcranial anatomy of mammals (e.g., Coillot et al. 2013; Argot 2013) and when useful, the corresponding terminology following the Nomina Anatomica Veterinaria (Waibl et al. 2005; Schaller 2007) is indicated in parentheses.

\section{LOCOMOTOR RECONSTRUCTION}

The locomotor reconstruction is based on direct observations on the specimens together with data from the literature. We distinguish locomotor categories and the following foot postures:

- Plantigrade: the heel (= calcaneus + astragalus) is placed completely flat on the ground during locomotion (Wang 1993; Polly 2010);

- Semi-digitigrade: the heel is occasionally in contact with the substrate at rest, but in motion the animal adopts a more digitigrade position (Polly 2010);

- Digitigrade: the animal stands on the distal ends of the middle metapodials and phalanges; the heel does not come into contact with the ground during locomotion (Wang 1993; Polly 2010).

For the locomotor categories, the following terms are used:

- Terrestrial: spends most time on the ground (Polly \& McLeod 2008). A terrestrial animal can be also cursorial;

- Scansorial: spends considerable time on the ground, but is also a good climber (Polly \& McLeod 2008);

- Arboreal: spends most of its time in trees (Polly \& McLeod 2008);

- Semifossorial: digs frequently for food and protection (Bastl 2012);

- Cursorial: forages over large areas. There are three types of cursorial mammals: 1) runner capable of prolonged trot-
TABLE 3. - Comparison of body mass (in $\mathrm{kg}$ ) estimated on the basis of the lower first molar (Van Valkenburgh 1990) for the amphicyonid genera known in the Paleogene of Europe, with indication of their stratigraphic distribution (MP levels). The body mass of all amphicyonids species are in Appendix 2.

\begin{tabular}{lll}
\hline Genus & Body mass & $\begin{array}{l}\text { Stratigraphic } \\
\text { distribution (MP) }\end{array}$ \\
\hline "Cynodictis" & $4-9$ & $19-21$ \\
Cynodictis & $5-9$ & $18-23$ \\
Symplectocyon & 7 & 21 \\
Goupilictis & 13 & $28-30$ \\
Cynelos & $23-42$ & $26-30$ \\
Haplocyon & $29-45$ & $29-30$ \\
Pseudocyonopsis & $29-73$ & $21-29$ \\
Harpagocyon & 35 & 29 \\
Brachycyon & 45 & $26-28$ \\
Haplocyonopsis & 86 & 30 \\
Ysengrinia & 96 & $29-30$ \\
Crassidia & 134 & $29-30$ \\
\hline
\end{tabular}

TABLE 4. - Estimation of body masses (in $\mathrm{kg}$ ) of the amphicyonids from Quercy Phosphorites based on astragalus (Tsubamoto 2014). The measurements used for the estimations are in Appendix 1.

\begin{tabular}{lc}
\hline Taxon/Morphotype & Estimated body mass \\
\hline Cynodictis lacustris & $1.042-1.843$ \\
Morphotype 1 & $7.846-16.566$ \\
Morphotype 2 & $18.091-21.225$ \\
Morphotype 3 & $0.812-2.783$ \\
Morphotype 4 & 1.806 \\
\hline
\end{tabular}

TABLE 5. - Calcaneal gear ratio (Polly 2010) estimated for C. lacustris and each morphotype.

\begin{tabular}{lc}
\hline Taxon/Morphotype & Gear ratio \\
\hline Morphotype A & 1.23 \\
Morphotype B & 1.25 \\
Morphotype C & 1.18 \\
C. lacustris & 1.27 \\
\hline
\end{tabular}

ting, but not fast (e.g., hyenas); 2) fast runner depending upon both speed and stamina (e.g., grey wolf); and 3) sprinters with fast acceleration for short distances (e.g., cheetah) (Taylor 1989).

Moreover, the calcaneal gear ratio helps in determining the posture and locomotion (Polly 2010). It corresponds to the calcaneal proximodistal length divided by the length from the proximal end of the calcaneus to the distal margin of the sustentaculum tali. We calculated the calcaneal gear ratio for each morphotype (Table 5) and compared them with gear ratios in Polly et al. (2017).

\section{INSTITUTIONAL ABBREVIATIONS}

MNHN.F Palaeontological collection of the Muséum national d'Histoire naturelle;

MNHN.F.Au fossil collection from Aubrelong;

MNHN.F.Qu fossil collection from the Quercy Phosphorites;

KUL.PLV1542 vertebrate fossil collection of KU Leuven;

ULgPA.17.170 collection of Quercy calcanei of the Universite de Liège;

ULgPA.17.175 collection of Quercy astragali of the Universite de Liège. 


\section{SYSTEMATIC PALAEONTOLOGY}

\section{CARNIVORAMORPHA Wyss \& Flynn, 1993 CARNIVORAFORMES}

Flynn, Finarelli \& Spaulding, 2010

Order CARNIVORA Bowdich, 1821

Suborder CANIFORMIA Kretzoi, 1943

Family AMPHICYONIDAE Trouessart, 1885

Genus Cynodictis Bravard \& Pomel, 1850

Cynodictis lacustris Gervais, 1852

(Fig. 2)

Holotype. - Fragmentary mandible bearing P4 and M1; MNHN.F.Qu unnumbered (Gervais 1852).

NEWLY REFERRED SPECIMENS. - Astragali. MNHN.F.Au1076, MNHN.F.Au3169, MNHN.F.Au847, MNHN.F.Au3186I, MNHN.F.Au984, MNHN.F.Au994, unnumbered specimen (astragalus + navicular).

Calcanei. MNHN.F.Au2188, MNHN.F.Au2699, MNHN.F.Au1059* MNHN.F.Au848, MNHN.F.Au2398, MNHN.F.Au2020, MNHN.F.Au991, MNHN.F.Au2044, MNHN.F.Au2118*, MNHN.F.Au618, MNHN.F.Au822, MNHN.F.Au2209*(10), MNHN.F.Au2705, MNHN.F.Au2703, MNHN.F.Au992, MNHN.F.Au976, MNHN.F.Au2471, MNHN.F.Au845, MNHN.F.Au2391, MNHN.F.Au2018, MNHN.F.Qu9699, MNHN.F.Qu9757.

Stratigraphic Distribution. - MP18-MP21 Priabonian - early Rupelian. It should be noted that some authors suggest that the genus is present up to MP23 (e.g., Kotsakis 1980: 268, 269).

TyPe LOCALITY. — La Débruge (Vaucluse, France).

LOCALITY. - Aubrelong (Lot, France).

AgE LOCALITY. - MP21, early Rupelian.

\section{REMARKS ON NEWLY REFERRED SPECIMENS}

These specimens are here identified as Amphicyonidae because of their morphological similarities with European and North American amphicyonids: astragalus with a medial projection of the head and the asymmetry of the trochlea; calcaneus with a rounded shape of the sustentacular facet and a slight tilt in a medioproximal-laterodistal orientation of the cuboid facet. Futhermore, the differences observed with other carnivoran clades found in the Quercy deposits (Table 1) allow us to differentiate the studied bones from these taxa, and to support the assignment to amphicyonids. The specimens are assigned to the species $C$. lacustris because of their geographic localization, small size, and high relative abundance (see Comparison for determination).

\section{Astragalus (TAlus) DESCRiption (Fig. 2A-E)}

\section{Dorsal view}

The trochlea (trochlea tali proximalis) is deeply excavated. Its proximodistal length is greater than its mediolateral length. The axis of elongation of the trochlea is inclined relative to that of the neck. Its medial and lateral lips are of approximately the same proximodistal length and are more or less parallel. The proximal plantar tuberosity is very small or absent. The neck (collum tali) is mediolaterally thinner than the head (caput tali) and is relatively short. The head is strongly distally convex. It is broad (wider than the mediolateral length of the trochlea) and projected on the medial side. It rises on the neck on the medial side of the astragalus and almost reaches the distal edge of the trochlea.

\section{Ventral view}

The ectal facet (facies articularis calcaneae lateralis) is proximodistally elongated and more distally distinct than proximally. It is strongly concave and its medial edge curves slightly. The sinus of the tarsus (sinus tarsi) is deep. It clearly separates the two facets for the articulation with the calcaneus (facies articulares calcaneae). The sustentacular facet (facies articularis calcaneae medialis) is quite large and occupies a large portion of the width of the neck. Its medial and distal edges are well marked. It is elongated and extends proximomedially towards the trochlea. The distolateral part of this facet extends to almost reach the head of the astragalus (caput tali). It is slightly convex except on its proximomedial extension, where it becomes concave. The foramen in the proximal portion of this sinus is present. The head has a small ventral extension that goes partly back to the sustentacular facet.

\section{Lateral view}

A slight depression is formed proximal to the fibular facet (facies malleolaris lateralis). The proximomedial edge of the fibular facet forms a nearly right angle with the distal edge. The distal edge is relatively distally convex in the extension of the lateral edge of the trochlea. The ectal facet is well curved.

\section{Distal view}

The trochlea is slightly asymmetrical. The head is dorsoventrally flattened, thinner on the medial side, and wider on its lateral side. The axis of elongation of the head is inclined relative to the mediolateral axis of the astragalus. The lateral process is limited in breadth, forming only a slight medially directed tip.

\section{Proximal view}

The trochlear foramen is present on some specimens and absent in others. The proximoventral edge of the medial lip of the trochlea forms a slight ventral tip. The plantar tendon groove (for the flexor digitorum fibularis) is very weak. It seems to be fused with the proximal prolongation of the trochlea. The trochlea is mediolaterally thinner on its proximal part than on its dorsal part.

\section{Calcaneus description (Fig. 2F-J) \\ Dorsal view}

The medial process of the tuber calcanei is slightly proximally broader than the lateral process. The sagittal groove is rather marked. The tuber calcane $i$ is not very mediolaterally broad but rather proximodistally elongated. The ectal facet (facies articularis talaris proximalis) is proximodistally elongated. It 


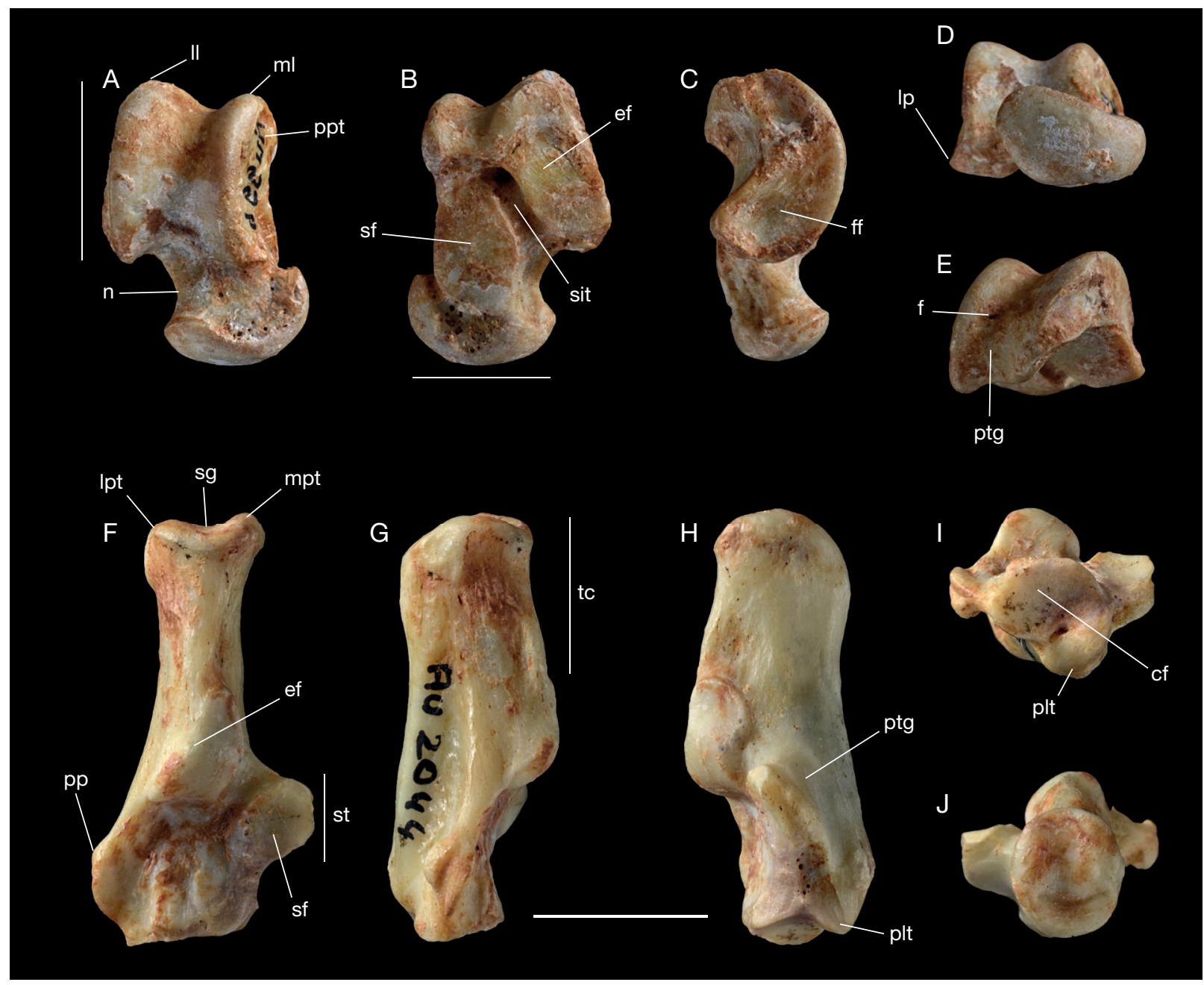

FIG. 2. - Tarsal bones of Cynodictis lacustris from Aubrelong (France; Rupelian, MP21): A-E, MNHN.F.Au994, left astragalus (reversed views); A, dorsal view; B, ventral view; C, lateral view; D, distal view; E, proximal view; F-J, MNHN.F.Au2044, right calcaneus; F, dorsal view; G, lateral view; H, medial view; I, distal view; J, proximal view. Abbreviations: cf, cuboid facet; ef, ectal facet; f, foramen; ff, fibular facet; h, head; II, lateral lip; Ip, lateral process; Ipt, lateral process of tuber; ml, medial lip; mpt, medial process of tuber; $\mathbf{n}$, neck; ppt, proximal plantar tuberosity; plt, plantar tubercle; pp, peroneal process; ptg, plantar tendon groove; sf, sustentacular facet; sg, sagittal groove; sit, sinus of the tarsus; st, sustentaculum tali; tc, tuber calcanei; tr, trochlea. Scale bar: $1 \mathrm{~cm}$.

is strongly convex in the middle and very slightly proximally and distally concave. Its medial and lateral edges are slightly curved. The edges of this facet are rather well marked, except the distal edge, which merges with the body of the calcaneus and therefore is difficult to delimit. The sustentacular facet (facies articularis talaris distalis) is slightly elongated in the proximolateral-distomedial direction and extends slightly on the proximal edge of the sustentaculum tali. This gives a rather oval shape to this articular surface. The peroneal process is quite broad. The cuboid facet (facies articularis cuboidea) is inclined with respect to the mediolateral axis and its lateral edge rises above the body of the calcaneus.

\section{Lateral view}

The dorsal and ventral edges of the tuber are very slightly curved; the tuber is dorsoventrally wide. A well marked ridge is formed at the continuity of the peroneal process and join more distally the tuber calcanei.

\section{Medial view}

The groove for the plantar tendon (sulcus tendinis musculus flexor digiti lateralis) is pronounced. The plantar tubercle is distally large, forming a distally oriented tip.

\section{Distal view}

The cuboid facet is very slightly concave, quite dorsoventrally thin and mediolaterally elongated. The plantar tubercle is ventrally broad. The edge separating these two structures is not very broad.

\section{Proximal view}

The distal part of the tuber calcanei has a rather oval surface that is slightly dorsoventrally elongated. A slightly curved groove is ventrally clearly visible.

\section{COMPARISON}

These tarsal elements are all from Aubrelong (France, MP21; except two specimens whose exact locality is unknown). 
Cynodictis lacustris differs from Hyaenodonta (e.g., Hyaenodon Laizer \& Parieu, 1838 from the Eocene of Europe [Bastl 2012] and Galecyon chronius Zack, 2011 from the Eocene of North America [Zack \& Rose 2015]) in its astragalus morphology which displays an astragalar neck that is less distomedially oriented and mediolaterally thinner; a head that extends less on the medial part of the neck, and a medial edge of the head that is more pronounced (Table 1). Moreover, the plantar tendon groove is less pronounced than the proximal plantar tuberosity and the lateral process is slenderer than in Hyaenodonta. For the calcaneus, the cuboid facet of C. lacustris is less inclined than in Indohyaenodon raoi Bajpai, Kapur \& Thewissen, 2009 (Ypresian, India; Rana et al. 2015) and Galecyon chronius (Eocene, North America; Zack \& Rose 2015).

Compared to Nimravidae, such as Hoplophoneus primaevus (Leidy \& Owen, 1851) and Nimravus brachyops (Cope, 1878) (Oligocene, North America; Barrett 2016), the astragalus of $C$. lacustris has a longer neck and the head extends less on the medial side of the neck. Its calcaneus has a thinner sustentaculum tali and a shallower plantar tendon groove than in Nimravidae.

Compared to Miacidae such as Vulpavus Marsh, 1871 (Eocene, North America; Heinrich \& Rose 1997), the tarsal bones of $C$. lacustris are smaller, the neck of the astragalus is shorter and less medially projected, and the plantar tendon groove is less pronounced and less dorsally extended. Moreover, the sustentaculum tali is not as medially broad and proximally located, and the cuboid facet is less inclined.

Cynodictis lacustris differs from Ursoidea (only modern forms because of the lack of ursid tarsal bones from the Paleogene or Miocene in the literature) (Gagnaison et al. 2017), such as Ursus spelaeus Rosenmüller, 1794 (early Pleistocene of Europe; Santi et al. 2005) and Ursus arctos Linnaeus, 1758 (Pleistocene of Europe; Baryshnikov 2015): the astragalus of $C$. lacustris is thinner, the neck is much longer, and the trochlea is mediolaterally narrower and is not flattened proximodistally. The tuber calcane $i$ is less stockier and mediolaterally thinner. The sustentaculum tali is less distally positioned and its sustentacular facet is shorter, more rounded, and not as inclined in the medioproximal-laterodistal direction.

In comparison with Ailuridae, such as Simocyon batalleri (Viret, 1929) (Miocene, Spain; Salesa et al. 2008), the astragalus of C.lacustris has a shallower trochlea, a shorter and mediolaterally broader neck, and a less flattened head. The sustentaculum tali of the calcaneus is proximodistally thinner, the cuboid facet is more inclined and the plantar tendon groove is less marked than in S. batalleri.

Compared with mustelids such as Martes sansaniensis Lartet, 1851, Ischyrictis zibethoides Blainville, 1841, and Taxodon sansaniensis Lartet, 1851 (Miocene, Europe; Peigné 2012), the astragalar neck of C. lacustris is shorter and less medially projected and the sustentacular facet is mediolaterally broader. The calcaneus of $C$. lacustris has a more inclined cuboid facet and a shorter plantar tubercle than in M. sansaniensis. The sustentaculum tali is proximodistally and mediolaterally narrower, the tuber calcanei is mediolaterally thinner and the peroneal process is proximodistally broader than in T. sansaniensis. Cynodictis lacustris also exhibits a smaller calcaneus as compared with I. zibethoides, with a sustentaculum tali that is proximodistally narrower and a thinner medial process of tuber.

All the features discussed above allow us to discriminate the Aubrelong amphicyonids from the other carnivorous groups recorded in Aubrelong and the Phosphorites du Quercy analysed in the framework of this study. The studied bones particularly resemble those of the Amphicyonidae, such as the European Amphicyon major Blainville, 1841 (Miocene) (Argot 2010) and the North American Amphicyon galushai Hunt, 2003 and Daphoenodon superbus Peterson, 1907 (Miocene) (Hunt 2009; 2011). In these four species, the head is mediolaterally broad and medially projected, while the trochlea is asymmetrical. Futhermore, the deep and relatively broad thochlea observed in C. lacustris is a characteristic of large amphicyonids according Gagnaison et al. (2017) as Amphicyon giganteus Schinz, 1825. Moreover, some differences are noticeable: for instance, the average length of the $C$. lacustris astragali $(14.91 \mathrm{~mm})$ is much less than the length of those of $A$. major, D. superbus and $A$. galushai (around $50 \mathrm{~mm}$ ) and the neck in C. lacustris is more elongated than in the other two species. The morphology of the calcaneus of Cynodictis lacustris is close to that of Amphicyon major. In these two species, the medial process of the tuber calcanei is proximally longer than the lateral process, the sustentacular facet is prolonged on its proximal edge, the tuber calcanei is quite thick dorsoventrally, and the cuboid facet is inclined with respect to the mediolateral axis. However, the cuboid facet is more inclined and more concave, the peroneal process is less broad and the sustentaculum tali is more distally prolonged in Amphicyon major than in Cynodictis lacustris.

The ratio of tarsal bone length/skull length of $C$. lacustris described here is similar to that of other amphicyonids. For instance, the ratio for Daphoenodon robustum Peterson, 1910 ranges between 0.14 to 0.16 for the astragalus and 0.24 to 0.26 for the calcaneus (Hunt 2009). In C. lacustris, the ratio for the astragalus ranges from 0.13 to 0.15 and for the calcaneus 0.18 to 0.26 . This ratio is also close to that of modern ursids: 0.11 to 0.14 for the astragalus and 0.18 to 0.22 for the calcanueus (Baryshnikov \& Boeskorov 2004; Baryshnikov 2015). Moreover, it is different from Hyaenodonta: astragalar ratio 0.09 to 0.11 , and calcaneal ratio of 0.13 (Bastl 2012). In S. batalleri (Ailuridae), the astragalar ratio is 0.17 and the calcaneal ratio is 0.25 . It is close to C. lacustris regarding the 1 (Salesa et al. 2008). The lack of data in the literature prevents us from calculating ratios for other fossil carnivoran clades.

Furthermore, the use of other criteria, such as relative abundance and size, allow us to be more specific and to attribute these tarsal bones to Cynodictis lacustris (Priabonian-Rupelian), primarily because this species is the only amphicyonid recognized based on dental and cranial elements in the Aubrelong locality (K. Le Verger pers. obs.). 
AMPHICYONIDAE Gen. indet.

Newly Referred specimens. - Astragali. Morphotype 1: MNHN.F.Qu9986, MNHN.F.Qu10038, KUL.PLV1542.1, KUL. PLV1542_2, KUL.PLV1542_3, KUL.PLV1542_4. - Morphotype 2: MNHN.F.Qu10231, KUL.PLV1542_5, KUL.PLV1542_6, KUL.PLV1542_7, KUL.PLV1542_8. - Morphotype 3: MNHN.F.Qu9570, MNHN.F.Qu9758, MNHN.F.Qu10369, MNHN.F.Qu10368, MNHN.F.Qu10372, MNHN.F.Qu10371, MNHN.F.Qu10042, MNHN.F.Qu10367, ULgPA.17.175_1, ULgPA.17.175_2, ULgPA.17.175_3. - Morphotype 4: MNHN.F.Qu10039.

Calcanei. Morphotype A: MNHN.F.Qu9845, MNHN.F.Qu10095, MNHN.F.Qu10230, MNHN.F.Qu10237, MNHN.F.Qu10284, MNHN.F.Qu10282, MNHN.F.Qu10344, MNHN.F.Qu10350, MNHN.F.Qu10349, MNHN.F.Qu10347, MNHN.F.Qu10351, ULgPA.17.170_1, ULgPA.17.170_2, ULgPA.17.170_3, ULgPA.17.170_4, ULgPA.17.170_5, ULgPA.17.170_6, ULgPA.17.170_7, ULgPA.17.170_8, ULgPA.17.170_9, ULgPA.17.170_10, ULgPA.17.170_11, ULgPA.17.170_12, ULgPA.17.170_13, ULgPA.17.170_14, ULgPA.17.170_15, ULgPA.17.170_16, ULgPA.17.170_17, ULgPA.17.170_18, ULgPA.17.170_19, KUL.PLV1542_9, KUL.PLV1542_10, KUL.PLV1542_11, KUL.PLV1542_12, KUL.PLV1542_13, KUL.PLV1542_14, KUL.PLV1542_15, KUL.PLV1542_16, KUL.PLV1542_17, KUL.PLV1542_18, KUL.PLV1542_19, KUL.PLV1542_20, KUL.PLV1542_21, KUL.PLV1542_22, KUL.PLV1542_23. - Morphotype B: MNHN.F.Qu10399, MNHN.F.Qu10005, MNHN.F.Qu10003, MNHN.F.Qu9775, MNHN.F.Qu10002, MNHN.F.Qu10381, MNHN.F.Qu10239, MNHN.F.Qu10346, MNHN.F.Qu9987, ULgPA.17.170_20, ULgPA.17.170_21, ULgPA.17.170_22, ULgPA.17.170_23, ULgPA.17.170_24, ULgPA.17.170_25, KUL.PLV1542_24, KUL. PLV1542_25, KUL.PLV1542_26, KUL.PLV1542_27, KUL. PLV1542_28. - Morphotype C: KUL.PLV1542_29.

STRATIGRAPHIC DisTRIBUTION. - MP18-MP30; Priabonian-Chattian.

LOCALITY. - Quercy (France), exact locality not indicated.

\section{REMARKS ON NEWLY REFERRED SPECIMENS}

These fossils are identified as Amphicyonidae because of their relative abundances, size, morphological similarities with European and North American amphicyonids and with C. lacustris described above, together with morphological differences from other carnivoran clades (Table 1). Moreover, relative abundance and body mass criteria support our identifications (see below). Although these bones are similar enough to those of amphicyonids to all be assigned to this family, morphological differences are noticeable between all these different specimens. These differences are perhaps representative of several amphicyonid genera or species, but so far more precise attribution is not possible, for lack of reliable arguments. For these reasons, they remain grouped into several morphotypes in this study, based on morphology and size (see Comparison for more details).

\section{ASTRAGALUS DESCRIPTIONS}

This set of astragalus morphotypes has the following characteristics. The trochlea is asymmetrical. Its mediolateral length is shorter than its proximodistal length. The axis of elongation of the trochlea is inclined relative to that of the neck. A depression is formed proximal to the fibular facet. The ectal facet is concave, proximodistally elongated and more distally thin. The sinus of the tarsus (sinus tarsi - sensu Schaller 2007) is deeply excavated. The sustentacular facet rises proximomedially towards the plantar tendon groove (for the flexor digitorum fibularis), as well as distolaterally to the head. This head is strongly distally convex and has a ventral extension that reaches back to the sustentacular facet. The head is dorsoventrally flattened, thinner on the medial side and wider on its lateral side. Four morphotypes are recognized among this sample of astragali due to differences in size and morphology.

\section{Morphotype 1 \\ (Fig. 3A-E)}

\section{Dorsal view}

The trochlea is somewhat shallow. Its medial and lateral edges are more or less parallel to each other and are of different proximodistal lengths, the lateral edge being much shorter than the medial one. The proximal plantar tuberosity is present and slightly broad. The neck is thin, short and more mediolaterally extended than the head. The head is broad and projected on the medial side. It has strongly pronounced edges, rising on the neck at the medial side of the astragalus and reaching the level of the most distal edge of the trochlea.

\section{Ventral view}

The medial and lateral edges of the ectal facet have fairly strong curvatures. The foramen at the proximal level of this sinus is visible on some specimens. The sustentacular facet is quite large and occupies a large part of the neck width. It looks almost rhomboidal and its edges are strongly marked. The facet is slightly convex except on its proximomedial extension, where it becomes concave.

\section{Lateral view}

The proximomedial edge of the fibular facet forms a nearly right angle with the distal edge. The distal edge is flat, giving the facet a rectangular appearance. The ectal facet is shallow.

\section{Distal view}

The head has a groove in the center. The axis of elongation of the head is in the mediolateral axis of the astragalus. The lateral process is poorly broad.

\section{Proximal view}

The proximoventral part of the medial edge of the trochlea forms a ventral tip. The trochlear foramen is absent. The tendinous plantar groove is strongly excavated, rather mediolaterally thin, inclined with respect to the axis of the trochlea, and very deep.

\section{Morphotype 2 \\ (Fig. 3F-J)}

\section{Dorsal view}

The trochlea is deeply excavated. The medial and lateral edges are relatively equal. The trochlea extends a little distally on the neck, almost forming a squatting facet. The proximal 
plantar tuberosity is weakly broad. The neck is thin and more mediolaterally extended than the head. The neck is longer than that of Morphotype 1 . The head is a little projected on the medial side (much less than in Morphotype 1) and its edges are not pronounced. It rises strongly on the medial edge of the neck, up to the level of the distal edge of the medial lip.

\section{Ventral View}

The ectal facet has little curvature on its medial and lateral margins. The foramen at the proximal level of this sinus is visible. The sustentacular facet is proximodistally elongated. Its lateral edge is rather marked, contrary to the other edges. The facet is slightly convex except on its proximomedial extension, where it becomes concave.

\section{Lateral view}

The edges of the fibular facet are relatively rounded, giving this facet a half-moon shape. The ectal facet is sharply convex.

\section{Distal view}

The axis of elongation of the head is inclined relative to the mediolateral axis of the astragalus. The lateral process is weak or absent.

\section{Proximal view}

The trochlear foramen is wide. The tendinous plantar groove is weakly excavated and is inclined almost $90^{\circ}$ with respect to the axis of the trochlea.

\section{Morphotype 3}

(Fig. 3K-O)

\section{Dorsal view}

The trochlea is weakly excavated. The medial and lateral lips are of different proximodistal length, the lateral being shorter than the medial. The proximal plantar tuberosity is very slightly broad. The neck is short. In two specimens (MNHN.F.Qu10042 and MNHN.F.Qu10367), the neck is slightly longer than in the others, but these two specimens do not differ enough to represent another morphotype. The head is broad and projected on the medial side. It has more pronounced edges on the lateral side than on the medial one and rises strongly on the medial edge of the neck, reaching the level of the most distal edge of the trochlea.

\section{Ventral View}

The medial and lateral edges of the ectal facet are curved (more on the medial than on the lateral edge). A foramen is visible at the proximal level. The sustentacular facet has a rhomboidal area. Its edges are marked. The facet is slightly convex except on its proximomedial extension, where it becomes concave. In two specimens (MNHN.F.Qu10042 and MNHN.F.Qu10367), the sustentacular facet is slightly less elongated and more proximally positioned on the body than in the others.

\section{Lateral view}

The edges of the fibular facet are relatively rounded, giving this facet a half-moon look, as in Morphotype 2. The ectal facet is sharply convex.

\section{Distal view}

The axis of elongation of the head is slightly inclined with respect to the mediolateral axis of the astragalus. The lateral process is only slightly broad.

\section{Proximal view}

The trochlear foramen is absent in some specimens and present in others. The proximoventral edge of the medial lip of the trochlea (trochlea tali proximalis) forms a small ventral point. The tendinous plantar groove is present but weakly excavated and is well inclined relative to the axis of the trochlea.

\section{Morphotype 4}

(Fig. 3P-T)

\section{Dorsal view}

The trochlea is shallow. The medial and lateral lips are more or less parallel to each other, but of different proximodistal lengths, and have a distal edge of the medial lip that is more proximal than the lateral lip. The proximal plantar tuberosity is a little broader than in Morphotype 3. The neck is longer than in Morphotype 3. The head is quite large and a little projected on the medial side. It has more pronounced edges than in Morphotype 3 and extends much less on the neck of the medial side of the astragalus. The medial edge of the head is well separated from the distal edge of the medial lip of the trochlea.

\section{Ventral view}

The medial and lateral edges of the ectal facet have a strong curvature. The sustentacular facet has a rhomboidal area. Its edges are well pronounced. This facet is slightly convex except on its proximomedial extension, where it becomes concave.

\section{Lateral view}

The proximomedial edge of the fibular facet is less rounded than in Morphotype 3 and therefore displays a somewhat rectangular shape. The ectal facet is sharply convex.

FIG. 3. - Astragali of undetermined amphicyonids from the Quercy (France; Priabonian-Chattian, MP18-MP30): A-E, Morphotype 1, MNHN.F.Qu10038, left astragalus (reversed views): A, dorsal view; B, ventral view; C, lateral view; D, distal view; E, proximal view; F-J, Morphotype 2, KUL.PLV1542_8, right astragalus: F, dorsal view; G, ventral view; H, lateral view; I, distal view; J, proximal view; K-O, Morphotype 3, MNHN.F.Qu9758, left astragalus (reversed views); K, dorsal view; L, ventral view; M, lateral view; N, distal view; O, proximal view; P-T, Morphotype 4, MNHN.F.Qu10039, right astragalus: P, dorsal view; Q, ventral view; 

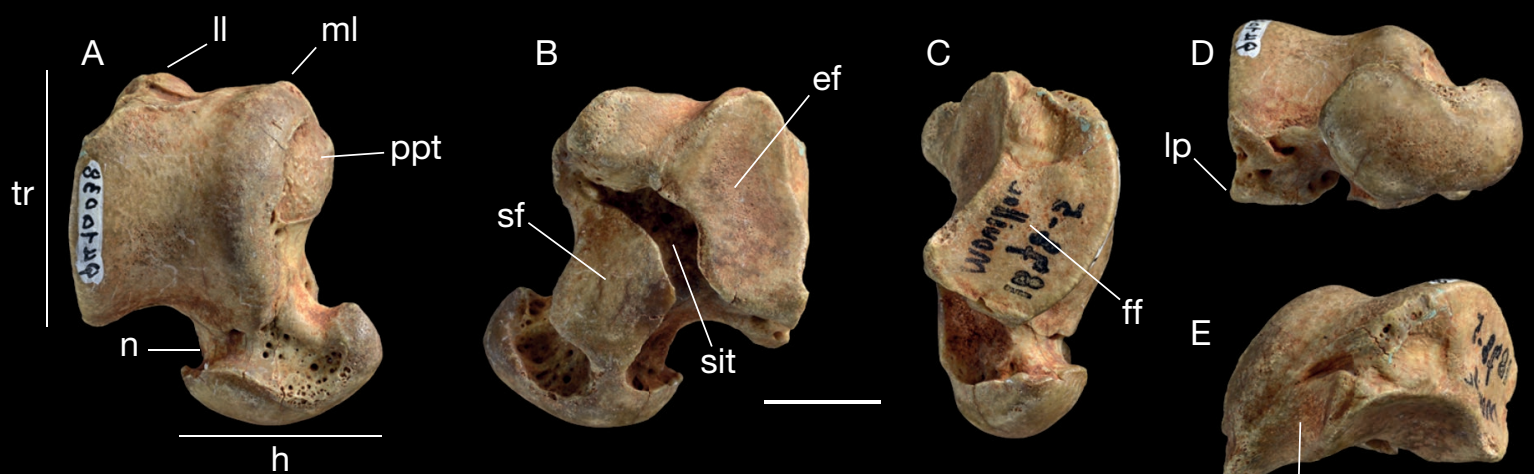

$\operatorname{ptg}$
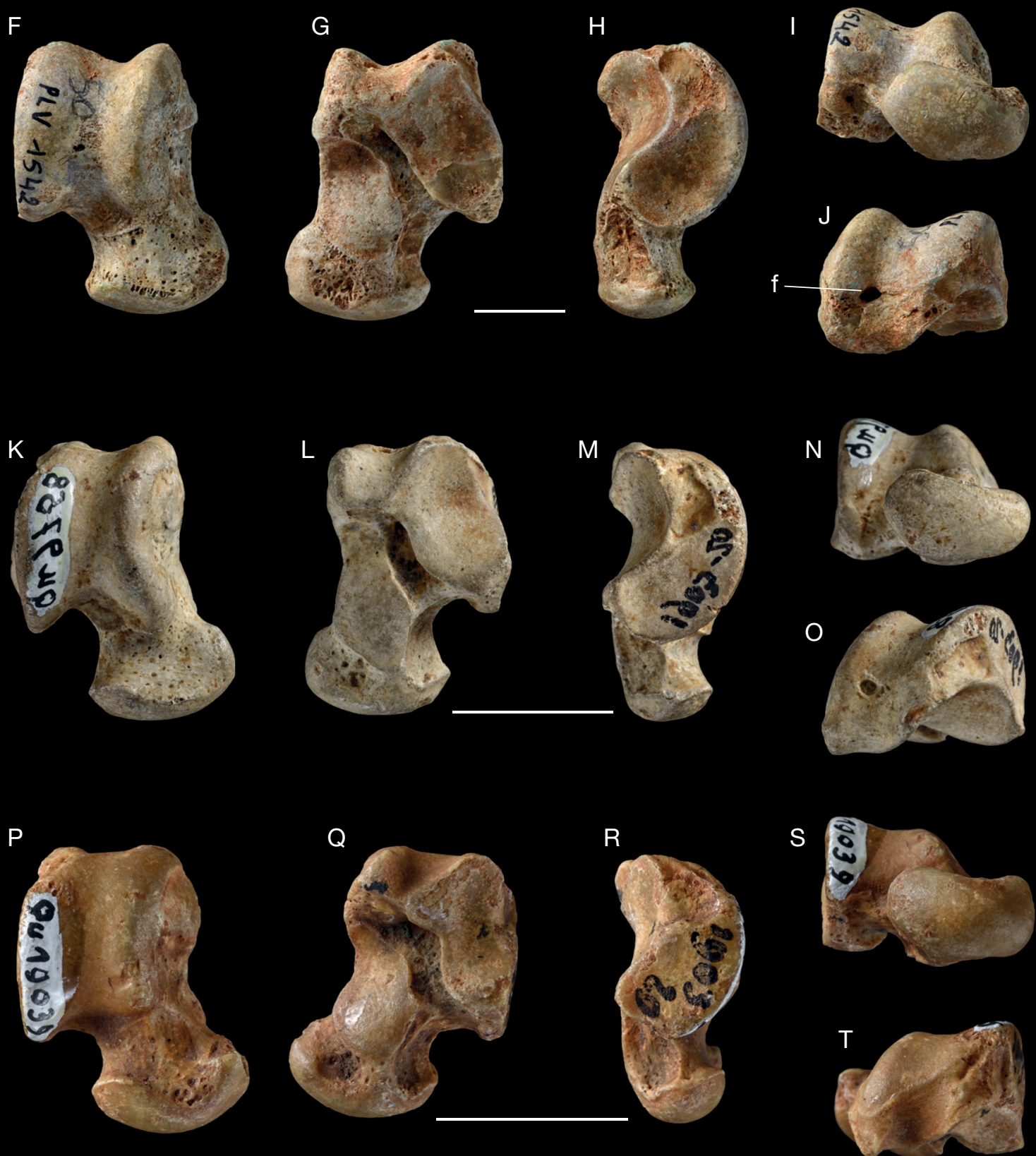

R, lateral view; S, distal view; T, proximal view. Abbreviations: ef, ectal facet; f, foramen; ff, fibular facet; h, head; II, lateral lip; Ip, lateral process; $\mathbf{m l}$, medial lip; $\mathbf{n}$, neck; ppt, proximal plantar tuberosity; ptg, plantar tendon groove; sf, sustentacular facet; sit, sinus of the tarsus; tr, trochlea. Scale bar: $1 \mathrm{~cm}$. 


\section{Distal view}

The axis of elongation of the head is along the mediolateral axis of the astragalus. The lateral process is very little broad.

\section{Proximal view}

The trochlear foramen is absent. The proximoventral edge of the medial lip of the trochlea forms a ventral tip. The plantar tendon groove is well marked, very inclined relative to the axis of the trochlea, and well excavated.

\section{CALCANEUS DESCRIPTIONS}

For all morphotypes, the medial process of the tuber calcanei is proximally longer than the lateral process. A groove on the proximal surface of the tuber calcanei, positioned rather ventrally, is clearly visible. The cuboid facet is larger mediolaterally than proximodistally. Three different morphotypes have been determined based on differences in size and morphology.

\section{Morphotype A \\ (Fig. 4A-E)}

\section{Dorsal view}

The sagittal groove is rather marked. The proximal part of the tuber calcanei is rather mediolaterally wide. It is rather proximodistally elongated, as is the ectal facet. This facet is highly convex. Its edges are rather well pronounced, except the distal one, which merges with the body of the calcaneus (and therefore is difficult to delimit). The sustentacular facet is well-rounded, very slightly concave, and extends on the proximal edge of the sustentaculum tali. The peroneal process is quite broad and its proximal edge is well-defined. The cuboid facet is inclined with respect to the mediolateral axis and its lateral edge rises slightly on the body of the calcaneus. This articular surface is strongly concave.

\section{Lateral view}

The dorsal and ventral edges of the tuber calcanei are slightly concave. A cavity - probably for the insertion of the lateral collateral ligament - is clearly visible proximal to the ectal facet.

\section{Medial view}

The tendinous plantar groove is well excavated. The sustentaculum tali is dorsoventrally quite thick, even more so than in Cynodictis lacustris and Morphotype B. The plantar tubercle does not form a distally directed tip as seen in Cynodictis lacustris.

\section{Distal view}

The plantar tubercle is ventrally broad. The edge separating the plantar tubercule and the cuboid facet is more visible than in Cynodictis lacustris.

\section{Proximal view}

The proximal part of the tuber calcanei has a sub-spherical surface. The groove is slightly more pronounced than in Cynodictis lacustris.

\section{Morphotype B}

(Fig. 4F-J)

\section{Dorsal view}

The sagittal groove is rather visible. The tuber calcanei is proximodistally quite elongated. The ectal facet is more inclined relative to the proximodistal axis than in other morphotypes, as well as in Cynodictis lacustris. It is strongly convex in the middle and very slightly concave in its proximal part. The edges of this facet are rather well pronounced, except the distal edge, which merges with the body of the calcaneus and is therefore difficult to delimit. The sustentacular facet is rounded and extends slightly on the proximal edge of the sustentaculum tali. It is placed more proximal on the body of the calcaneus than in the other two calcaneal morphotypes. The peroneal process and its proximal and distal edges are quite well defined. The cuboid facet is inclined with respect to the mediolateral axis and its lateral edge rises over the body of the calcaneus. The plantar tubercle is distally very long and clearly visible in dorsal view. It is longer than that of Cynodictis lacustris.

\section{Lateral view}

The dorsal and ventral edges of the tuber calcanei are very slightly concave. The cavity, proximal to the ectal facet, is deep and positioned higher on the tuber than in Morphotype A.

\section{Medial view}

The tendinous plantar groove is quite excavated.

\section{Distal view}

The cuboid facet is smaller than in Morphotype A. The plantar tubercle is ventrally quite broad. The edge separating these two structures is not very clear.

\section{Proximal view}

The proximal part of the tuber calcanei has a rather oval surface that is slightly dorsoventrally elongated.

\section{Morphotype C}

(Fig. 4K-O)

\section{Dorsal view}

The sagittal groove is poorly defined. The tuber calcanei is proximodistally quite elongated. The ectal facet is convex in the middle and very slightly concave in its proximal part. The edges of this facet are rather clear, except the distal edge, which merges with the body of the calcaneus (and is therefore difficult to delimit). The sustentaculum tali has a rounded articular surface, as in Morphotypes A and B, and extends slightly on the proximal edge. The peroneal process is not broad and merged with the ridge extending up on the tuber calcanei. The cuboid facet is concave and inclined with respect to the mediolateral axis, but its lateral edge does not extend up the body of the calcaneus as seen in Morphotypes $\mathrm{A}$ and $\mathrm{B}$. 


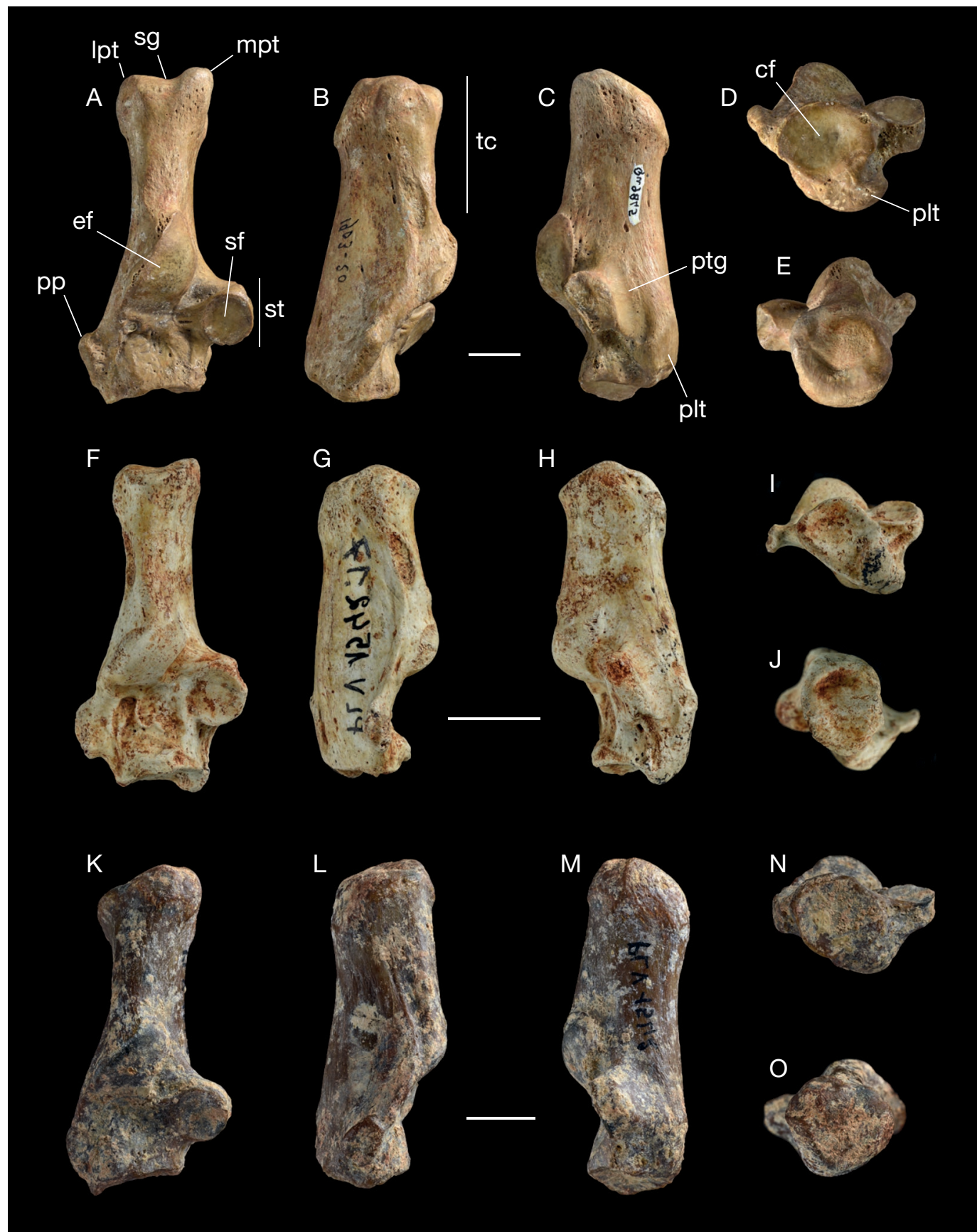

FIG. 4. - Calcanei of undetermined amphicyonids from the Quercy (France; Priabonian-Chattian, MP18-MP30): A-E, Morphotype A, MNHN.F.Qu9845, left calcaneus (reversed views): A, dorsal view; B, lateral view; C, medial view; D, distal view; E, proximal view; F-J, Morphotype B, KUL.PLV1542 28, left calcaneus (reversed views); F, dorsal view; G, lateral view; H, medial view; I, distal view; J, proximal view; K-O, Morphotype C, KUL.PLV1542_29, left calcaneus (reversed views): K dorsal view; L, lateral view; $\mathbf{M}$, medial view; $\mathbf{N}$, distal view; $\mathbf{O}$, proximal view. Abbreviations: cf, cuboid facet; ef, ectal facet; Ipt, lateral process of tuber; mpt, medial process of tuber; pp, peroneal process; plt, plantar tubercle; ptg, tendinous plantar groove; sg, sagittal groove; sf, sustentacular facet; st, sustentaculum tali; tc, tuber calcanei. Scale bar: $1 \mathrm{~cm}$

\section{Lateral view}

The dorsal and plantar edges of the tuber calcanei are very slightly concave. The cavity, which is proximal to the ectal facet, is not very deep.

\section{Medial view}

The tendinous plantar groove is not very marked. The sustentaculum tali is dorsoventrally quite thick, as in Morphotype A.

\section{Distal view}

The plantar tubercle is ventrally well broad.

\section{Proximal View}

The edges of the proximal part of the tuber calcanei are quite irregular. 


\section{COMPARISON}

These morphotypes exhibit morphological differences from tarsal bones of Hyaenodonta, such as G. chronius (Zack \& Rose 2015) and Hyaenodon (Bastl 2012). The neck of the astragalus is mediolaterally thinner and the medial edge of the head is more pronounced in these morphotypes. The plantar tendon groove is less pronounced, the proximal plantar tuberosity and the lateral processes are slenderer. The calcaneus of the morphotypes has a much less inclined cuboid facet than in I. raoi (Rana et al. 2015) and G. chronius (Zack \& Rose 2015).

In comparison with Nimravidae, such as $H$. primaevus and $N$. brachyops (Barrett 2016), all astragalus morphotypes have a longer neck and the head extends less on the medial side of this neck. The calcanei have a thinner sustentaculum tali and a shallower plantar tendon groove than in Nimravidae.

Compared to Miacidae such as Vulpavus (Heinrich \& Rose 1997), the tarsal bones of the morphotypes are smaller, and the four astragalar morphotypes have a shorter neck, which is less medially projected, and a less pronounced plantar tendon groove, which is less dorsally extended. Moreover, the sustentaculum tali is medially thinner and not as distally positioned as in Vulpavus.

These morphotypes are also very different from those of Ursoidea such as Ursus spelaeus (Santi et al. 2005) and Ursus arctos (Baryshnikov 2015). They have less robust tarsal bones, the neck of the astragalus is much longer and the trochlea is mediolaterally thinner. The tuber calcanei is mediolaterally narrower, the sustentaculum tali is less distally positioned and its sustentacular facet is more rounded, not as elongated, and not inclined in the medioproximal-laterodistal direction as observed in ursoids.

Compared to the ailurid Simocyon batalleri (Salesa et al. 2008), the morphotypes have a less flattened astragalar head, and a mediolaterally broader sustentacular facet. The sustentaculum tali is proximodistally thinner, the peroneal process is mediolaterally and proximodistally thinner and the plantar tendon groove is less marked than in S. batalleri.

Compared to mustelids such as M. sansaniensis, I. zibethoides and T. sansaniensis (Peigné 2012), the astragalar neck of the morphotypes is shorter and less medially projected, and he sustentacular facet is mediolaterally broader. The calcaneus morphotypes are larger with a more rounded sustentaculum tali.

All these differences exclude an assignment of the bones to Hyaenodonta, Nimravidae, Miacidae, Ursidae, Ailuridae or Mustelidae and indicate a close relationship to amphicyonids. The astragalus of Morphotypes 1, 3, and 4 is very similar to that generally observed in Amphicyonidae such as Amphicyon major (Argot 2010), Amphicyon galushai (Hunt 2009), and the North American Ysengrinia americana Wortman, 1901 (OligoMiocene) (Hunt 2002). The head is relatively projected on the medial side of the astragalus and quite broad; the trochlea is asymmetrical and its mediolateral width is greater than its proximodistal length. Futhermore, Morphotype 1 displays a relatively large trochlea, just as Morphotype 2, which also features a deep trochlear articulation. These characteristics are present in large amphicyonids such as Amphicyon giganteus (Miocene of Europe and Africa; Gagnaison et al. 2017). Despite these morphological similarities, these three morphotypes display some differences from these amphicyonids (i.e., $A$. major, A. galushai, and $Y$. americana). The neck of Morphotype 1 is mediolaterally thinner and proximodistally shorter, and the fibular facet is dorsoventrally thicker than in Morphotypes 3 and 4. Moreover, Morphotype 1 is taller than the two others. The neck of Morphotype 3 is proximodistally longer and the head edges are less marked than in the others. In Morphotype 4 , the distal edge of the trochlea medial lip is more proximal than the lateral lip and the plantar tendon groove is more marked. Morphotype 2 is assigned to Amphicyonidae because of its strong resemblance to the amphicyonid Daphoenodon robustum (North America, Miocene) (Hunt 2009). Indeed, the shape of the trochlea, relatively well excavated, the elongated neck, and the shape of the head, which is not mediolaterally wide in comparison to the width of the neck, are observed in Daphoenodon robustum.

The morphology of the calcaneus Morphotype A is closely similar to that of Amphicyon galushai (Hunt 2009), which also has a broad tubercle on its proximal part that is much thinner on its distal part. Moreover, the sustentacular facet is rounded and distally placed. Morphotype B is similar to the specimen of Daphoenodon robustum illustrated in Hunt (2009). The sustentaculum tali is more proximally located than in the other morphotypes. The plantar tubercle is ventrally and distally long, forming a tip at the cuboid facet. Morphotype $\mathrm{C}$ is morphologically similar to the calcaneus of the European Amphicyon lathanicus Ginsburg, Cheneval, Janvier, Pouit \& Sen, 2000 (Miocene) (Ginsburg 2002). The sustentaculum tali is distally located, the cuboid facet is inclined with respect to the mediolateral axis and is distally strongly concave. Its morphology is also strongly similar to that of Cynelos lemanensis Pomel, 1846 (Peigné \& Heizmann 2003), Afrocyon ginsburgi Morales, Pickford, Soria \& Fraile, 1998 (Morales et al. 2016) and Amphicyon longiramus White, 1942 (Olsen 1960). The four amphicyonids share the following features: the peroneal process is poorly broad, the sustentaculum tali is distally positioned and the cuboid facet is concave. Moreover, the sustentacular facet is rounded in both $C$. lemanensis and Morphotype C. At the opposite side, the sagittal groove is more defined and the tuber calcanei is distally a little thinner in $C$. lemanensis. Relative abundance and body mass (see below) support the attribution of these morphotypes to amphicyonids, but they cannot be further assigned to infra-familial ranks.

\section{RELATIVE ABUNDANCES}

In almost all collections studied here, amphicyonids are by far the most abundant group (Table 2). This is also true for the dental specimens of this carnivoran group in the ULiege collection, with $30.73 \%$. Amphicyonids are not the most abundant carnivorans in the KUL collection, but still represent $31.03 \%$ of the assemblage, making it the second most abundant group in this collection after Ursoidea (39.66\%). The high relative abundance of amphicyonid tarsal bones is thus congruent with the high relative abundance of amphicyonids based on dental remains. 


\section{BODY MASS ESTIMATION}

The body mass estimated for Cynodictis lacustris based on its astragalus ( 1 to $2 \mathrm{~kg}$; Table 4 ) is lower than the values obtained from dental material (c. $5 \mathrm{~kg}$; Table 3). For the European amphicyonids, the body mass estimated from the lower first molar varies between 4 and $134 \mathrm{~kg}$ (Table 3 ). This range is very broad and is greater than the values obtained for the four astragalar morphotypes. Morphotypes 1 and 2 fall within this range, but Morphotypes 3 and 4 are just outside this range with values below $3 \mathrm{~kg}$; one can note that the latter case is similar to that of $C$. lacustris (Table 4).

Among the amphicyonids recorded in the Paleogene of Europe (Table 3), body masses between 5 and $10 \mathrm{~kg}$ correspond to the genera Cynodictis, Symplectocyon Springhorn, 1979, and "Cynodictis" (C. exilis Teilhard de Chardin, 1915 and "C." palmidens Teilhard de Chardin, 1915). Therefore, Morphotypes 3 and 4 might correspond to these genera.

Morphotype 1 groups heavier specimens (between 8 and $17 \mathrm{~kg}$ based on astragalus; Table 4). Because it seems that the body masses estimated from the astragalus are lower than those estimated from the $\mathrm{m} 1$, Morphotype 1 could correspond to the smallest species of Cynelos, Cynelos rugosidens Schlosser, 1899 or Cynelos crassidens Filhol, 1876 ( $\approx 23-24 \mathrm{~kg}$ ). Some specimens could also correspond to the Oligocene amphicyonid Goupilictis Ginsburg, 1969 (13 kg).

Finally, Morphotype 2 could also include specimens that correspond to the genus Cynelos Jourdan, 1862. It may also include representatives of the genera Pseudocyonopsis Kuss, 1965 and Haplocyon Schlosser, 1901 (Table 3).

Interestingly these new tarsal bones indicate significant differences in body mass within the same family (Table 4), as does the dental material (Table 3). Furthermore, there are no specimens that may correspond to the largest European amphicyonids Brachycyon Filhol, 1872, Harpagocyon Springhorn, 1977, Ysengrinia Ginsburg, 1965, Haplocyonopsis Bonis, 1973, and Crassidia Heizmann \& Kordikova, 2000. It is worth noting that these genera are only known in the Chattian (MP26-MP30). Thus, the astragali studied here might come from Priabonian and Rupelian localities, except if some belong to Goupilictis.

\section{LOCOMOTION}

Posture and locomotion significantly affect the morphology of the tarsal bones (Szalay \& Decker 1974; Jenkins \& McClearn 1984; Taylor 1989). The crurotarsal joint, where the tibia and astragalus are in contact, is the main axis of flexion of the foot. The posture is therefore related to the morphology of this articulation (Wang 1993). The calcaneus, which articulates with the astragalus, also has an important role in the movement of the hindlimb because of the insertion of the $m$. gastrocnemius and $m$. soleus. They attach to its distal end via the achilles tendon, which constitutes the main lever of plantar flexion (Barone 2000). Among the Carnivora, two postures are recognized: plantigrady and digitigrady. Some authors define an intermediate state present in many extant Mustelidae and Viverridae: semi-digitigrady (Wang 1993; Polly 2008).
TABLE 6. - Comparison of postures estimated on the basis of the astragalus and calcaneus.

\begin{tabular}{lll}
\hline Taxa/Morphotype & Posture & Locomotion \\
\hline Cynodictis lacustris & Digitigrade & Cursorial ? \\
Morphotype 1 & Plantigrade & - \\
Morphotype 2 & Semidigitigrade & - \\
Morphotype 3 & Plantigrade & - \\
Morphotype 4 & Plantigrade & - \\
Morphotype A & Plantigrade & Terrestrial ? \\
Morphotype B & Semidigitigrade & Terrestrial ? \\
Morphotype C & Plantigrade & - \\
\hline
\end{tabular}

It appears that the absence of the trochlear foramen and a tendinous groove in digitigrade predators allows the tibia to rotate over the entire surface of the trochlea and thus to have a greater amplitude of flexion-extension (Wang 1993). According to Ginsburg (1961), an elongated astragalus is associated with digitigrade locomotion. Carrano (1997) remarked that the orientation of the astragalus head is a distinctive element between digitigrade and plantigrade postures: the head is oriented in the same direction as the body in dorsal view in a plantigrade mammal, whereas in a digitigrade mammal, it is inclined relative to the direction of the body of the astragalus. According to Polly (2008), in a digitigrade animal the calcaneal ectal facet is sharply convex, the peroneal process is small, the sustentaculum tali is more proximally and posteriorly positioned, and the astragalar ectal facet is sharply curved. In plantigrade animals: the calcaneal ectal facet is rounded, the peroneal process is long, the sutentaculum tali is larger and distally positioned, the astragalar neck is narrow, and the astragalar ectal facet is shallow. Finally, the presence of large and flat facets on these two bones causes a reduction of intertarsal mobility (Polly 2008).

All the postures and locomotion hypothesized for the sample presented herein are listed in Table 6. Morphotype 1 has a plantar tendinous groove, and the head is not inclined towards the mediolateral axis. The ectal facet is shallow, as for Ailurus fulgens Cuvier, 1825 (Ailuridae) and Bassaricyon gabbii Allen, 1876 (Procyonidae), two plantigrade species (Polly 2008). It has a narrow neck and an ectal facet that is shallow. These characters suggest that Morphotype 1 corresponds to a plantigrade animal. Morphotype 2 has a longer neck than in Morphotype 1 , and a head that is slightly inclined towards the mediolateral axis. The neck is also larger and the ectal facet is sharply curved, as observed in Canis lupus Linnaeus, 1758 (Canidae), Felis catus Linnaeus, 1758, Leptailurus serval (Schreber, 1776), and Lynx rufus (Schreber, 1777) (Felidae), which are all digitigrade (Polly 2008). Morphotype 2 therefore better corresponds to a digitigrade animal. Moreover, it strongly resembles the astragalus of the North American amphicyonid Daphoenodon robustum, which was considered a digitigrade animal capable of powerful propulsive force (Hunt 2009). However, Morphotype 2 has a tendinous groove, which is placed fairly ventrally on the trochlea and weakly excavated. Flexion-extension should therefore have moderate amplitude, but more than a plantigrade animal with a strongly defined 
tendinous groove. Daphoenodon robustum does not appear to have a tendinous groove (Hunt 2009 does not mention this structure, which is also not visible on the illustrations). Because of this morphology, Morphotype 2 is probably better characterized as a semi-digitigrade animal. Morphotypes 3 and 4 have a head that is oriented on the mediolateral axis as well as a plantar tendon groove, like in the plantigrade species used in Carrano's (1997) analyses and Procyon lotor Linnaeus, 1758 (Procyonidae) (Wang 1993). The neck is long and narrow and the ectal facet is well curved (deeper in Morphotype 3 than in Morphotype 4), as in B. gabbii and $A$. fulgens, which are plantigrade mammals (Polly 2008). Morphotypes 3 and 4 are therefore interpreted as plantigrade, but the latter displays a larger range of movements enabled by a less deep trochlear surface.

Morphotypes A and C have a rounded sutentaculum tali that is rather distal; this structure is even more distal in Morphotype C, as observed in A. fulgens and B. gabbii, which are plantigrade (Polly 2008). This would therefore be characteristic of a plantigrade animal. However, in Morphotype $\mathrm{C}$, the peroneal process is poorly broad, which seems to be a digitigrade feature (e.g., L. serval; Polly 2008). The gear ratio for morphotype $\mathrm{A}$ is 1.23 (Table 5), which is similar to that of Vulpes velox (Say, 1823) (Canidae; digitigrade, terrestrial), Spilogale gracilis (Linnaeus, 1758) (Mephitidae; plantigrade, terrestrial), Taxidea taxus (Schreber, 1777) (Mustelidae; plantigrade, semifossorial), and Nasua narica (Linnaeus, 1766) (Procyonidae; plantigrade, scansorial) (Polly 2010; Polly et al. 2017). The gear ratio for Morphotype C (1.18; Table 5) is similar to that of Tremarctos ornatus (Cuvier, 1825) (Ursidae; Plantigrade, scansorial), Potos flavus (Schreber, 1774) (Procyonidae; plantigrade, arboreal) and Galictis vittata (Schreber, 1776) (Mustelidae; plantigrade, semi-fossorial) (Yensen \& Tarifa 2003; Polly 2010; Polly et al. 2017). Morphotypes A and C may therefore correspond to plantigrade amphicyonids. Morphotype B has a more proximal sustentaculum tali, as in F catus and L. rufus (Polly 2008). In addition, its morphology is close to that of the calcaneus of Daphoenodon robustum, which is digitigrade as indicated above (Hunt 2009). It also resembles the specimen of the Miocene digitigrade Plithocyon ursinus Cope, 1875 in North America (Paleontological Collection of MNHN), which also has a proximal sustentaculum tali and a distally long plantar tubercle. On the other hand, the peroneal process is well broad and the sustentaculum tali is located a little more dorsally, which seem to be plantigrade features (e.g., A. fulgens; Polly 2008). Even if the sustentaculum tali is more proximal than the other morphotypes, it is still far distal relative to extant digitigrade carnivorans (e.g., F. catus; Polly 2008). The gear ratio for Morphotype B is 1.25 (Table 5), which is close to P. lotor (semi-digitigrade, scansorial), Martes americana (Turton, 1806) (Mustelidae; plantigrade, scansorial) and Conepatus chinga (Molina, 1782) (Mephitidae; semi-digitigrade, terrestrial) (Polly 2010; Polly et al. 2017). Morphotype B would therefore rather be a semidigitigrade and terrestrial or scansorial animal, but probably not cursorial (gear ratio less than 1.22).
The head of the astragalus of Cynodictis lacustris is inclined with respect to the mediolateral axis and the tendinous groove seems to merge with the trochlea, as in the digitigrade Urocyon cinereoargenteus (Schreber, 1775) (Wang 1993). However, the neck is quite short and the astragalar ectal facet is well curved, as in F. catus and L. rufus which are digitigrade and scansorial. In addition, the sustentaculum tali of the calcaneus is not placed very distally, as can be observed in a digitigrade animal (e.g., C. lupus; Polly et al. 2017). The gear ratio is 1.27 for C. lacustris (Table 5), which is similar to Vulpes vulpes (Linnaeus, 1758) (Canidae; digitigrade, terrestrial), Canis latrans Say, 1823 (Canidae; digitigrade, terrestrial), Canis rufus Audubon \& Bachman, 1851 (Canidae; digitigrade, terrestrial), and Panthera onca Linnaeus, 1758 (Felidae; digitigrade, scansorial) (Polly et al. 2017). The canid species (i.e., Canis Linnaeus, 1758 and Vulpes Frisch, 1775) are all cursorial (Polly et al. 2017). Therefore, Cynodictis lacustris can be considered as digitigrade and cursorial.

Interpretations are more contentious regarding locomotion. Based on the model of Polly \& MacLeod (2008), the calcaneus of Cynodictis morphology is intermediate between the terrestrial and the scansorial morphologies. Morphotypes $\mathrm{A}$ and $\mathrm{C}$ are between the arboreal and terrestrial morphologies. But the specimens used for the implementation of this model are all extant animals and, in the case of plantigrady, the majority of the specimens are arboreal. Therefore, Polly \& MacLeod's (2008) model links plantigrady and arborality. While it is true that arboreal animals are often plantigrades (Taylor 1989; Panciroli et al. 2017), plantigrades are not necessarily arboreal (Wang 1993). Morphotypes A and C do not exhibit a large sustentaculum tali, in contrast to arboreal animals. Therefore, Morphotypes A and C may represent terrestrial predators.

\section{CONCLUSIONS}

This work describes for the fist time the tarsal bones of carnivoran mammals from the Quercy Phosphorites (Eocene, France). Based on morphology, relative abundances, size, and estimated body mass, we refer numerous astragali and calcanei to Amphicyonidae, some of which are assigned to Cynodictis lacustris. However, the absence of previously identified carnivoran tarsal bones from the Quercy, as well as the lack of exact locality information of the old Quercy collections precludes a finer identification of the seven morphotypes we describe.

Isolated postcranial bones are rarely described for European amphicyonids. Neither Eocene nor Oligocene tarsals have as yet been described from European localities. This work demonstrates that it is possible to identify these bones, some even at the species level.

The morphological diversity of the tarsal bones of this study confirms that European amphicyonids from the Paleogene displayed a wide diversity in their locomotion and posture, as is seen in the American amphicyonids. Three main postures are here identified, although the boundary between them is sometimes tenuous: plantigrade (Morphotypes 1, 3, 
4, A and C), semi-plantigrade (Morphotype 2 and B), and digitigrade (Cynodictis lacustris). Including postcranial bones other than these two tarsal bones would surely help to better determine the posture, locomotion, and hunting strategies (e.g., pursuit, ambush).

At least one amphicyonid survived the "Grande Coupure": the digitigrade and potential runner Cynodictis lacustris. Nonetheless, and in the absence of accurate age information of the fossiliferous deposits, it remains impossible to reconstruct the evolution of amphicyonid locomotion on either side of this important turnover.

Finally, of potential interest in the taxonomic determination of carnivoran postcranial bones is their use for phylogenetic analyses, mostly because they are likely to provide phylogenetic signals different from those provided by the dentition. Improving our knowledge of the phylogeny of Amphicyonidae is crucial to reconstruct this radiation.

\section{Acknowledgements}

We thank Christine Argot and Guillaume Billet (CR2P) for access to the material housed in the MNHN Paleontological Collections. The photographs were taken by Lilian Cazes (CR2P). We are very grateful to Lars Werdelin, Gema Siliceo and David Polly for their helpful insight which improved the quality of this manuscript. We thank Louis de Bonis for organizing this memorial in tribute to S. Peigné. This work took place in Stéphane's office, which was always open to students (and to any nice colleague wanting to chat in front of the coffee machine). We express here our warmest thoughts to Stéphane and his family.

This work was supported by the BELSPO Brain Pioneer project BR/175/PI/CARNAGES, and the ATM Blanche MNHN 2018 (project Grande-Coupure). The MNHN gives access to the collections in the framework of the RECOLNAT national Research Infrastructure.

\section{REFERENCES}

Allen J. A. 1876. - Description of a new generic type (Bassaricyon) of Procyonida, from Costa Rica. Proceedings of the Academy of Natural Sciences of Philadelphia 28: 20-23. https://www.jstor. org/stable/4059944

ARGOT C. 2010. - Morphofunctional analysis of the postcranium of Amphicyon major (Mammalia, Carnivora, Amphicyonidae) from the Miocene of Sansan (Gers, France) compared to three extant carnivores: Ursus arctos, Panthera leo, and Canis lupus. Geodiversitas 32 (1): 65-106. https://doi.org/10.5252/g2010n1a2

ARGOT C. 2013. - Postcranial Analysis of Carnivoran-like Archaic Ungulate: The case of Arctocyon primaevus (Arctocyonidae, Mammalia) from the late Paleocene of France. Journal of Mammalian Evolution 20: 83-114. https://doi.org/10.1007/s10914-012-9198-x

AudubOn J. \& BACHMAN J. 1851. - The Quadrupeds of North America. Vol. 2. V. G. Audubon, New York, 446 p. https://doi. org/10.5962/bhl.title. 51130

BajPaI S., Kapur V. V. \& TheWISSEN J. G. M. 2009. — Creodont and condylarth from the Cambay Shale (Early Eocene, 55-54MA), Vastan Lignite Mine, Gujarat, Western India. Journal of the Palaeontological Society of India 54: 103-109.
BARRETT P. Z. 2016. - Taxonomic and systematic revisions to the North American Nimravidae (Mammalia, Carnivora). PeerJ 4: e1658. https://doi.org/10.7717/peerj.1658

BARONE R. 2000. - Anatomie comparée des mammiferes domestiques. Tome 2. Arthrologie et myologie. Vigot, France, 988 p.

BARYSHNiKOV G. F. 2015. - Late Pleistocene Ursidae and Mustelidae remains (Mammalia, Carnivora) from Geographical Society Cave in the Russian far east. Proceedings of the Zoological Institute RAS 319 (1): 3-22.

BARYSHNikOv G. F. \& BoesKorov G. G. 2004. - Skull of the Pleistocene brown bear (Ursus arctos) from Yakutia, Russia. Russian Journal of Theriology 3 (2): 71-75. https://doi.org/10.15298/ rusjtheriol.03.2.04

BASTL K. 2012. - Ecomorphology of the European Hyaenodon. PhD, University of Vienna, Fakultät für Lebenswissenschaften, 300 p.

BIOCHROM'97 1997a. — Étalonnage de l'échelle biochronologique mammalienne du Paléogène d'Europe occidentale: Vers une intégration à l'échelle globale, in AgUILAR J.-P., LEgENDRE S. \& MichaUX J. (eds), Actes du colloque international de biostratigraphie BiochroM'97. École pratique des Hautes Études, Institut de Montpellier, Montpellier: 461-473 (Mémoires et Travaux de l'EPHE; 21).

BIOCHROM'97 1997b. - Synthèses et corrélations, in AGUILAR J.-P., Legendre S. \& MichauX J. (eds), Actes du colloque international de biostratigraphie BiochroM'97. École pratique des Hautes Études, Institut de Montpellier, Montpellier: 769-805 (Mémoires et Travaux de l'EPHE; 21).

BlainVILle H.-M. D. DE 1841. - Ostéographie ou description iconographique comparée du squelette et du système dentaire des cinq classes d'animaux vertébrés récents et fossiles pour servir de base à la zoologie et à la géologie - Mammiferes carnassiers: Des Petits-Ours (G.Subursus). J.B.Baillière, Paris, 123 p. https://doi. org/10.5962/bhl.title.127351

BONIS L. DE 1973. - Contribution à l'étude des Mammiferes de l'Aquitanien de l'Agenais. Rongeurs - Carnivores - Périssodactyles. Muséum national d'Histoire naturelle, Paris, 192 p. (Mémoires du Muséum national d'Histoire naturelle, Sér. C - Sciences de la Terre; 28). https://www.biodiversitylibrary.org/page/59329411

BONIS L. DE 2011. - A new species of Adelpharctos (Mammalia, Carnivora, Ursidae) from the late Oligocene of the "Phosphorites du Quercy" (France). Estudios Geológicos 67: 179-186. https:// doi.org/10.3989/egeol.40553.181

Bonis L. DE, Crochet J.-Y., RAge J.-C., Sigé B, Sudre J. \& VianeyLiAUD M. 1973. - Nouvelles faunes de vertébrés oligocènes des phosphorites du Quercy. Bulletin du Muséum national d'Histoire naturelle, série C, Sciences de la Terre 28, 174: 105-113. https:// www.biodiversitylibrary.org/page/55480076

BowDICH T. E. 1821. - An Analysis of the Natural Classifications of Mammalia, for the Use of Students and Travellers. J. Smith, Paris, 180 p.

BRAVARD A. \& POMEL A. 1850. - Notice sur les ossements fossiles de La Débruge, près d'Apt. Impression J.-S. Jean, 8 p.

CARRANO M. T. 1997. - Morphological indicators of foot posture in mammals: a statistical and biomechanical analysis. Zoological Journal of the Linnean Society 121: 77-104. https://doi. org/10.1111/j.1096-3642.1997.tb00148.x

Coillot T., Smith R., Gigase P. \& Smith T. 2013. - Tarsal diversity in the earliest Eocene mammal fauna of Dormaal, Belgium. Geologica Belgica 16: 274-283. https://popups.uliege. be:443/1374-8505/index.php?id=4293

Cope E. D. 1875. - On fossil Lemurs and Dogs. Proceedings of the Academy of Natural Sciences of Philadelphia 27: 255, 256. https:// www.biodiversitylibrary.org/page/1677174

Cope E. D. 1878. - On some of the characters of the Miocene fauna of Oregon. Proceedings of the American Philosophical Society 18: 63-78. https://www.biodiversitylibrary.org/page/26877837

Cuvier G. F. 1825. - Tremarctos ornatus, in SAINT-Hilaire E. G. \& Cuvier G. F. (eds), Histoire naturelle des Mammiferes, avec des figures originales, coloriées, dessinées d'après des animaux vivans. Tome 3. A. Belin, Paris. https://doi.org/10.5962/bhl.title.78766 
ESCARGUEL G. \& LEGENDRE S. 2006. — New methods for analyzing deep-time meta-community dynamics and their application to the Paleogene mammals from the Quercy and Limagne area (Massif Central, France). Strata 1: 245-273.

Escarguel G., Legendre S. \& Sigé B. 2008. — Unearthing deep-time biodiversity changes: The Palaeogene mammalian metacommunity of the Quercy and Limagne area (Massif Central, France). Comptes Rendus Geoscience 340: 602-614. https:// doi.org/10.1016/j.crte.2007.11.005

FilHOL H. 1872. - Recherches sur les mammifères fossiles des dépôts de phosphates de chaux dans les départements du Lot, du Tarn et de Tarn-et-Garonne. Première Partie. Carnassiers et Chiroptères. Annales des Sciences géologiques 3: 1-31.

FilHol H. 1876. - Recherches sur les Phosphorites du Quercy. Étude des fossiles qu'on y rencontre et spécialement des mammiferes. Première partie. Vol. 15. Bibliothèque de l'École des Hautes Études, Sciences naturelles, Paris: 1-220.

Finarelli J. A. 2008. - A total evidence phylogeny of the Arctoidea (Carnivora: Mammalia): Relationships among basal taxa. Journal of Mammalian Evolution 15: 231-259. https:// doi.org/10.1007/s10914-008-9074-x

Flynn J. J., Finarelli J. A. \& Spaulding M. 2010. — Phylogeny of the Carnivora and Carnivoramorpha, and the use of the fossil record to enhance understanding of evolutionary transformations, in Goswami A. \& Friscia A. (eds), Carnivoran Evolution: New Views on Phylogeny, Form, and Function. Cambridge University Press, Cambridge: 25-63. https://doi.org/10.1017/ CBO9781139193436.003

FrISCH J. L. 1775. - Das NaturSystem der vierfüssigen Thiere, in Tabellen: darinnen alle Ordnungen, Geschlechte und Arten, nicht nur mit bestimmenden Benennungen, sondern beygesetzten unterscheidenden Kennzeichen angezeigt werden, zum Nutzen der erwachsenen Schuljugend. Günther, 30 p.

Gagnaison C., Cossard B., \& DeChampS M. 2017. — À propos de quelques dents et os de mammifères carnivores du Miocène de l'Anjou-Touraine. Symbioses 35-36 : 47-60.

GERVAIS P. 1852. - Zoologie et paléontologie françaises (animaux vertébrés) ou nouvelles recherches sur les animaux vivantes et fossiles de la France. Arthus Bertrand, Paris, 146 p. https://doi. org/10.5962/bhl.title.39473

GĖZE B. 1974. - Sur le remplissage des poches a phosphorite» d'Aubrelong (commune de Bach, Lot). Palaeovertebrata 6: 21-25.

GinsBurg L. 1961. - Plantigradie et digitigradie chez les carnivores fissipèdes. Mammalia 25: 1-21. https://doi.org/10.1515/ mamm.1961.25.1.1

Ginsburg L. 1965. — L' "Amphicyon" ambiguus des Phophorites du Quercy. Bulletin du Muséum national d'Histoire naturelle, Série 2, 37: 724-730. https://www.biodiversitylibrary.org/ page/55113069

Ginsburg L. 1966. - Les Amphicyons des Phosphorites du Quercy. Annales de Paléontologie 52: 23-64.

GiNsBURG L. 1969. - Sur un Amphicyoninae de l'Oligocène d'Europe. Comptes Rendus sommaires des Séances de la Société géologique de France 3: 72, 73.

GINSBURG L. 2002. — Les carnivores fossiles des sables de l'Orléanais. Annales de Paléontologie 88: 115-146. https://doi.org/10.1016/ S0753-3969(02)01042-X

Ginsburg L., Cheneval J., Janvier P., Pouit D. \& Sen S. 2000. - Les Vertébrés des sables continentaux d'âge orléanien inférieur (MN3) de Mauvières à Marcilly-sur-Maulne (Indreet-Loire), La Brosse à Meigné-le-Vicomte (Maine-et-Loire) et Chitenay (Loir-et-Cher). Geodiversitas 22: 597-631.

Goswami A. \& Friscia A. 2010. - Carnivoran Evolution: New Views on Phylogeny, Form, and Function. Cambridge University Press, Cambridge, 523 p. https://doi.org/10.1017/CBO9781139193436

HeinRICH R. E. \& Rose K. D. 1997. — Postcranial morphology and locomotor behaviour of two early eocene miacoid carnivorans, Vulpavus and Didymictis. Palaeontology 40 (2): 279-305.
Heizmann E. P. J. \& Kordikova E. G. 2000. - Zur systematischen Stellung von "Amphicyon" intermedius H. V. Meyer, 1849 (Carnivora, Amphicyonidae). Carolinea 58: 69-82.

HunT JR R. M. 1977. - Basicranial anatomy of Cynelos Jourdan (Mammalia: Carnivora), an Aquitanian amphicyonid from the Allier Basin, France. Journal of Paleontology 51: 826-843. https:// www.jstor.org/stable/1303745

Hunt JR R. M. 1996. - Amphicyonidae, in Prothero D. R. \& ROBERT J. E. (eds), The Terrestrial Eocene-Oligocene Transition in North America. Cambridge University Press, Cambridge: 476-485. https://doi.org/10.1017/CBO9780511665431.024

HunT JR R. M. 1998. — Amphicyonidae, in JANIS C. M., SCOTT K. M. \& JACOBS L. L. (eds), Evolution of Tertiary Mammals of North America. Cambridge University Press, Cambridge: 196-227.

HunT JR R. M. 2002. - Intercontinental Migration of Neogene Amphicyonids (Mammalia, Carnivora): Appearance of the Eurasian Beardog Ysengrinia in North America. American Museum Novitates 3384: 1-53. http://doi.org/b364fw

HUNT JR R. M. 2003. - Intercontinental migration of large mammalian carnivores: earliest occurrence of the Old World beardog Amphicyon (Carnivora, Amphicyonidae) in North America. Bulletin of the American Museum of Natural History 279: 77-115. http://doi.org/cd347d

HunT JR R. M. 2009. — Long-legged pursuit carnivorans (Amphicyonidae, Daphoeninae) from the early Miocene of north America. Bulletin of the American Museum of Natural History 318: 1-95. http://hdl.handle.net/2246/5948

HUNT JR R. M. 2011. - Evolution of large carnivores during the mid-cenozoic of North America: the Temnocyonine radiation (Mammalia, Amphicyonidae). Bulletin of the American Museum of Natural History 358: 1-153. https://doi.org/10.1206/358.1

Hough J. R. 1948. - A systematic revision of Daphoenus and some allied genra. Journal of Paleontology 22: 573-600. https:// www.jstor.org/stable/1299593

JenKINS JR F. A. \& MCCLEARN D. 1984. - Mechanisms of hind foot reversal in climbing mammals. Journal of Morphology 182:197219. https://doi.org/10.1002/jmor.1051820207

JOURDAN M. 1862. - La description de restes fossiles de grands Mammifères. Part 2. Les terrains sidérolithiques. Revue des Société savantes, publiée sous les auspices du Ministère de l'Instruction publique et des Cultes 1: 126-130.

KOTSAKIS T. 1980. - Revisione sistematica e distribuzione stratigrafica e geografica del genere Cynodictis Bravard \& Pomel (Carnivora, Mammalia). Bollettino della Societa Paleontologica Italiana 19: $259-273$

KRETZOI M. 1943. - Kochitiis centenii n.g. n. sp. Ein altertümlicher Creodonte aus dem Oberoligozän. Föltdany Közlöny 73: 10-17 (https://www.biodiversitylibrary.org/page/50730209), 190-195 (https://www.biodiversitylibrary.org/page/50730389).

Kuss S. 1965. - Revision der europaïschen Amphicyoninae (Canidae, Carnivora, Mamm.) ausslich der vorober Stampischen Formen. Sitzungsberichte der Heidelberger Akademie der Wissenschaften Abhandlung 1: 1-168.

LAIZER L. \& PARIEU J. DE 1838. — Description et détermination d'une mâchoire fossile appartenant àun mammifere jusqu'à présent inconnu, Hyaenodon leptorhynchus. Comptes-rendus hebdomadaires des Séances de l'Académie des Sciences 7: 442. https://gallica.bnf. fr/ark:/12148/bpt6k29662/f442.item

LANGE-BADRÉ B. 1970. - Sur l'existence d'un gisement fossilifère d'âge oligocène inférieur dans les phosphorites du Quercy. Société géologique de France 5: 150-151.

LANGE-BADRÉ B. 1979. - Les Créodontes (Mammalia) d'Europe occidentale de l'Éocène supérieur à l'Oligocène supérieur. Muséum national d'Histoire naturelle, Paris, 249 p. (Mémoires du Muséum national d'Histoire naturelle, Sér. C - Sciences de la Terre ; 42). https://www.biodiversitylibrary.org/page/58403278

LARTET E. 1851. - Notice sur la colline de Sansan, suivie d'une récapitulation des diverses espèces d'animaux vertébrés fossiles, 
trouvés soit à Sansan, soit dans d'autres gisements du terrain tertiaire du miocène dans le bassin sous-pyrénéen. J.A. Portes, Auch, 45 p. https://hdl.handle.net/2027/hvd.32044107355059

LEGENDRE S. 1989. - Les communautés de mammifères du Paléogène (Éocène supérieur et Oligocène) d'Europe occidentale: structures, milieux et évolution. Münchner Geowissenschaftliche. Abhandlungen Reihe A: Geologie und Paläontologie 16: 1-110.

LEgENDRE S. \& HARTENBERgER J.-L. 1992. - Evolution of mammalian faunas in Europe during the Eocene and Oligocene, in Prothero D. R. \& BergGren W. A. (eds), Eocene-Oligocene Climatic and Biotic Evolution. Princeton University Press, Princeton: 516-528. http://www.jstor.org/stable/j.ctt7zvp65.31

Legendre S., Crochet J.-Y., Godinot M., Hartenberger J.-L., Marandat B., Remy J. A., Sigé B., Sudre J. \& VianeyLiAUD M. 1991. - Évolution de la diversité des faunes de mammifères d'Europe occidentale au Paléogène (MP 11 à MP 30). Bulletin de la Société géologique de France 162: 867-874. https:// doi.org/10.2113/gssgfbull.162.5.867

Legendre S., Sigé B., Astruc J. G., Bonis L. de, Crochet J. Y., Denys C., Godinot M., Hartenberger J.-L., LeVêque F., Marandat B., Mourer-Chauviré C., Rage J. C., Remy J. A., Sudre J. \& Vianey-Liaud M. 1997. — Les phosphoriytes du Quercy: 30 ans de recherche. Bilan et perspectives. Geobios 20: 331-345. https://doi.org/10.1016/S0016-6995(97)80038-1

LEIDY J. 1852 (for 1851). - December 16th. Proceedings of the Academy of Sciences of Philadelphia 5: 329-330.

LINNAEUS C. 1758. - Systema natura per regna tria natura, secundum classes, ordines, genera, species, cum characteribus, differentiis, synonymis, locis. Volume 1. Salvius, Holmiæ, 824 p. https://doi. org/10.5962/bhl.title.542

LINNAEUS C. 1766. - Systema nature per regna tria nature, secundum classes, ordines, genera, species, cum characteribus, differentiis, synonymis, locis. Editio Duodecima, Reformata. Impensis Direct. Salvius, Holmiæ. https://doi.org/10.5962/bhl.title.559

Maitre E. 2014. - Western European middle Eocene to early Oligocene Chiroptera: systematics, phylogeny and palaeoecology based on new material from the Quercy (France). Swiss Journal of Palacontology 133: 141-242. https://doi.org/10.1007/s13358014-0069-3

Maitre E., Hugueney M., Astruc J. G., Crochet J.-Y., Escarguel G., Godinot M., Legendre S., Marandat B., MourerChauviré C., Rage J.-C., Remy J. A., Simon-Coinçon R., Sudre J., VAlette P. \& Sigé B. 2006. - Huit nouvelles faunes éocènes et oligocènes des Phosphorites du Quercy. Strata, Série 1 13: 113-127.

MARSH O. C. 1871. - Notice of some new fossil mammals and birds from theTertiary formations of the West. American Journal of Science, Series 32 : 120-127. https://doi.org/10.2475/ajs. s3-2.8.120

MattheW W. D. \& Granger W. 1924. - New Carnivora from the Tertiary of Mongolia. American Museum Novitates 104: 1-9. http://hdl.handle.net/2246/3213

Molina J. I. 1782. - Saggio sulla storia naturale del Chili. Nella Stamperia di S. Tommaso d'Aquino, Bologna, Italy, 368 p. https:// bibdigital.rjb.csic.es/idurl/1/9635

Morales J., Pickford M., Soria D. \& Fraile S. 1998. - New carnivores from the basal Middle Miocene of Arrisdrift, Namibia. Eclogae Geologicae Helvetiae 91: 27-40.

Morales J., Pickford M. \& Valenciano A. 2016. — Systematics of African Amphicyonidae, with descriptions of new material from Napak (Uganda) and Grillental (Namibia). Journal of Iberian Geology 42 (2): 131-150. https://doi.org/10.5209/ rev_JIGE.2016.v42.n2.51960

OlsEN S. J. 1960. — The fossil carnivore Amphicyon longiramus from the Thomas farm Miocene. Part II - postcranial skeleton. Bulletin of the Museum of Comparative Zoology 123: 1-45. https:// www.biodiversitylibrary.org/page/2808983
Panciroli E., Janis C. \& Stockdale M. 2017. — Correlates between calcaneal morphology and locomotion in extant and extinct carnivorous mammals. Journal of Morphology 278: 13331353. https://doi.org/10.1002/jmor.20716

Peigné S. \& Bonis L. DE 1999. - The genus Stenoplesictis Filhol (Mammalia, Carnivora) from the Oligocene deposits of the Phosphorites of Quercy, France. Journal of Vertebrate Paleontology 19: 566-575. https://doi.org/10.1080/02724634.1999.10011165

PEIGNÉ S. 2000. - A new species of Eofelis (Carnivora: Nimravidae) from the Phosphorites of Quercy, France. Comptes Rendus de l'Académie des Sciences, Series IIA, Earth and Planetary Science 330 (9): 653-658. https://doi.org/10.1016/S1251-8050(00)00199-3

Peigné S. \& Heizmann P. J. 2003. - The Amphicyonidae (Mammalia: Carnivora) from Ulm-Westtangente (MN 2, Early Miocene), Baden-Württemberg, Germany - Systematics and ecomorphology. Stuttgarter Beiträge zur Naturkunde, Serie B 343: 133 p.

Peigné S. 2012. - Les Carnivora de Sansan, in Peigné S. \& Sen S. (eds), Mammiferes de Sansan. Muséum national d'Histoire naturelle, Paris: 559-660 (Mémoires du Muséum national d'Histoire naturelle ; 203)

PéLIssié T. 2015. - Le paléokarst des Causses du Quercy, in Les inventaires du Géopatrimoine: Enjeux, bilans et perspectives. Congrès international. Muséum d'Histoire naturelle de Toulouse, Toulouse: 22-26.

Peterson O. 1907. - The Miocene beds of western Nebraska and eastern Wyoming and their vertebrate faunae. Annals of the Carnegie Museum 4: 21-72. https://www.biodiversitylibrary.org/ page/39790849

PETERSON O. 1910. - Description of new carnivores from the Miocene of western Nebraska. Memoirs of the Carnegie Museum 4: 205-278. https://www.biodiversitylibrary.org/page/34978348

Petter G. 1966. - Cynodictis: Canidé oligocène d'Europe, région tympanique et affinités. Annales de Paléontologie 52: 1-19.

PolLy P. D. 2008. — Adaptive zones and the pinniped ankle: A 3D quantitative analysis of carnivoran tarsal evolution, in SARGIS E. \& DAgOSTO M. (eds), Mammalian Evolutionary Morphology: A Tribute to Frederick S. Szalay. Springer, Dordrecht: 165-194. https://doi.org/10.1007/978-1-4020-6997-0_9

Polly P. D. 2010. - Tiptoeing through the trophics: geographic variation in carnivoran locomotor ecomorphology in relation to environment, in Goswami A. \& FrISCIA A. (eds), Carnivoran Evolution: New Views on Phylogeny, Form, and Function. Cambridge University Press, Cambridge: 374-410. https://doi. org/10.1017/CBO9781139193436.014

Polly P. D. \& MACLeOd N. 2008. - Locomotion in Fossil Carnivora: An Application of Eigensurface Analysis for Morphometric Comparison of 3D Surface. Palaeontologia Electronica 11, 10A: 1-13

Polly P. D., Fuentes-Gonzales J., Lawing A. M., Bormet A. K. \& Dundas R. G. 2017. — Clade sorting has a greater effect than local adaptation on ecometric patterns in Carnivora. Evolutionary Ecology Research 18: 61-95.

POMEL A. 1846. - Note sur des animaux fossiles découverts dans le département de l'Allier. Bulletin de la Société géologique de France 4: 378-385.

RAGE J.-C. 2006. - The lower vertebrates from the Eocene and Oligocene of the Phosphorites du Quercy (France): an overview. Strata, Série 1 13: 161-173.

Rana R. S., Kumar K., Zack S. P., Solé F., Rose K. D., Missiaen P., Singh L., SAHNi A. \& SMith T. 2015. — Craniodental and postcranial morphology of Indohyaenodon raoi from the early Eocene of India, and its implications for ecology, phylogeny, and biogeography of hyaenodontid mammals. Journal of Vertebrate Paleontology: e965308, 22 p. https://doi.org/10.1080/0272463 4.2015.965308

Remy J.-A., Crochet J.-Y., Sigé B., Sudre J., Bonis L. De, VianeyLiaud M., Godinot M., Hartenberger J.-L., LANGe-Badré B. \& ComTe B. 1987. — Biochronologie des phosphorites du 
Quercy: mise à jour des listes fauniques et nouveaux gisements de mammiferes fossiles. Münchner Geowissenschaftliche Abhandlungen, Reihe A, Geologie und Paläontologie 10: 169-188.

Renault P., Guillot P. L., Lefavrais-Raymond A., SeronieVivien M. R., Cavaillé A. \& Clottes J. 1978. — Géologie du Quercy. Les suppléments de Quercy Recherche, Série Études et Travaux 4: 1-111.

ROSENMÜLLER J. C. 1794. — Quaedam de ossibus fossilibus animalis cuiusdam, historiam eius etcognitionem accuratiorem illustrantia. Dissertatio, quam d. 22. Octob. 1794 ad disputandumproposuit Ioannes Christ. Rosenmüller Heßberga-Francus, LL.AA.M. in Theatro anatomico Lipsiensi Prosector assumto socio Io. Chr. Aug. Heinroth Lips. Med. Stud. Cum tabula aenea, Leipzig, 34 p.

Salesa M. J., Anton M., Peigne S. \& Morales J. 2008. — Functional anatomy and biomechanics of the postcranial skeleton of Simocyon batalleri (Viret, 1929) (Carnivora, Ailuridae) from the Late Miocene of Spain. Zoological Journal of the Linnean Society 152 : 593-621. https://doi.org/10.1111/j.1096-3642.2007.00370.x

SANTI G., Rossi M. \& FONTE A. 2005. - Morphometry of the limb bones of the Ursus spelaeus RosenMÜLLER, 1794 from Valstrona (Piedmont-Northern Italy). Revue de Paléobiologie 24 (2) : 597-616.

SAY T. 1823. - Canis velox, in Account of an Expedition from Pittsburgh to the Rocky Mountains, Performed in the Years 1819, 1820 (compiled by JAMES E.). Vol. 2. Carey and Lea, Philadelphia, 356 p. https://doi.org/10.5962/bhl.title.61116

SCHALLER O. 2007. - Illustrated Veterinary Anatomical Nomenclature. 2nd edition. Enke Verlag, Stuttgart, 614 p.

SCHINZ H. R. 1825. - Das Thierreich eingetheilt nach dem Bau der Thiere als Grundlage ihrer Naturgeschiechte und der vergleichenden Anatomie von dem Herrn Ritter von Cuvier. Volume 4. Stuttgart and Tübingen, 792 p. https://doi.org/10.5962/bhl.title.120173

SCHLosser M. 1899. - Über die Bären und bärenähnlichen Formen des europäischen Tertiärs. Palaeontographica, Abteilung A 46: $95-148$

SCHLOSSER M. 1901. - Zur Kenntniss der Säugetierfauna der böhmischen Braunkohlenformation. Abhandlungen des Deutschen Naturwissenschaftlich - Medicinischen Vereines fur Bohmen "Lotos" $2(3)$.

SCHREBER J. C. D. 1774. - Die Saugthiere in Abbildungen nach der Natur, mit Beschreibungen. Erster Theil, Erlangen: Vol. 1 (9): 187, pl. 42. https://doi.org/10.5962/bhl.title.67399

SCHREBER J. C. D. 1775. — Die Säugthiere in Abblidungen nach der Natur mit Beschreibungen. Dritter Theil, Erlangen: Vol. 2 (13): pl. 92 [1776, Vol. 21: 361]. https://doi.org/10.5962/bhl.title.67399

SCHREBER J. C. D. 1776. — Die Säugthiere in Abblidungen nach der Natur mit Beschreibungen. Dritter Theil, Erlangen: Vol. 3 (16): pl. 108 [1977: 407]; Vol. 3 (18): pl. 124; 3 (26): 418. https:// doi.org/10.5962/bhl.title.67399

SCHREBER J. C. D. 1777. — Die Säugthiere in Abblidungen nach der Natur mit Beschreibungen. Dritter Theil, Erlangen: Vol. 3 (25): 412, pl. 109; Vol. 3 (26): pl. 142 [1778: 520]. https://doi. org/10.5962/bhl.title.67399

SolÉ F., Falconnet J. \& Yves L. 2014. - New proviverrines (Hyaenodontida) from the early Eocene of Europe; phylogeny and ecological evolution of the Proviverrinae. Zoological Journal of the Linnean Society 171: 878-917. https://doi.org/10.1111/ zoj. 12155

Solé F., Amson E., Borths M., Vidalenc D., Morlo M. \& Bastl K. 2015. - A new large hyainailourine from the Bartonian of Europe and its bearings on the evolution and ecology of massive hyaenodonts (Mammalia). Plos One 10: e0135698. https://doi. org/10.1371/journal.pone.0135698

Solé F., Fischer V., Denayer J., Speijer R. P., Fournier M., Le Verger K., Ladevèze S., Folie A. \& Smith T. (in press). The upper Eocene-Oligocene carnivorous mammals from the Quercy Phosphorites (France) housed in Belgian collections. Geologica Belgica.
Spaulding M. \& FlynN J. J. 2012. — Phylogeny of the Carnivoramorpha: The impact of postcranial characters. Journal of Systematic Palaeontology 10: 653-677. https://doi.org/10.1080 /14772019.2011.630681

SPRINGHORN R. 1977. - Revision der alttertiären europäischen Amphicyonidae (Carnivora, Mammalia). Palaeontographica Abteilung A 158 (1-3): 26-113.

STEHLIN H. G. 1910. - Remarques sur les faunules de mammifères des couches éocènes et oligocènes du Bassin de Paris. Bulletin de la Société géologique de France 9: 488-520.

SZALAY F. S. \& DECKER R. L. 1974. - Origins, evolution, and function of the tarsus in Late Cretaceous Eutheria and Paleocene primates, in FARISH JenKINS A. JR (ed.), Primate Locomotion. Academic Press: 223-259. https://doi.org/10.1016/B978-0-12384050-9.50013-1

SZALAY F. S. \& LuCAS S. G. 1996. - The postcranial Morphology of Paleocene Chriacus and Mixodectes and the Phylogenetic Relationships of Archontan Mammals. Bulletin of New Mexico Museum of Natural History and Science 7: 1-47.

TAYLOR M. E. 1989. - Locomotor adaptations by carnivores, in GitTleman J. L. (ed.), Carnivore Behavior, Ecology, and Evolution. Cornell University Press, Ithaca: 382-409. https://doi. org/10.1007/978-1-4757-4716-4_15

Teilhard de Chardin P. 1915. - Les Carnassiers des Phosphorites du Quercy. Annales de Paléontologie 9 : 101-192.

Tomiya S. \& Tseng Z. J. 2016. - Whence the beardogs? Reappraisal of the Middle to Late Eocene 'Miacis' from Texas, USA, and the origin of Amphicyonidae (Mammalia, Carnivora). Royal Society Open Science 3: 160518. https://doi.org/10.1098/rsos.160518

TrouessarT E. 1885. - Catalogue des mammifères vivants et fossiles - Carnivores. Bulletin de la Société d'Études scientifiques d'Angers 15 (suppl. issue): 1-108. https://doi.org/10.5962/bhl. title.63808

TSUBAMOTO T. 2014. - Estimating body mass from the astragalus in mammals. Acta Palaeontologica Polonica 59: 259-265.

TURTON W. 1806. - A General System of Nature: Through the Three Grand Kingdoms of Animals, Vegetables, and Minerals, Systematically Divided into their Several Classes, Orders, Genera, Species, and Varieties, with their Habitations, Manners, Economy, Structure, and Peculiarities. Lackington, Allen, and Co., Temple of the Muses, Finsbury-Square, London. https://doi.org/10.5962/ bhl.title. 37018

Vandenberghe N., Hilgen F. J., Speijer R. P., OgG J. G., Gradstein F. M., Hammer O., Hollis C. J. \& HoOKer J. J. 2012. - The Paleogene Period. The Geologic Time Scale: 855-921.

VAN VALKENBURGH B. 1985. — Locomotor diversity within past and present guilds of large predatory mammals. Paleobiology 11: 406-428. https://doi.org/10.1017/S0094837300011702

VAN VALKenBURGH B. 1990. - Skeletal and dental predictors of body mass in carnivores. Body Size, in DAMUTH J. \& MACFADDEN B. J. (eds), Mammalian Paleobiology. Estimation and Biological Implications. Cambridge University Press, Cambridge: 181-206.

VIRET J. 1929. — Les faunes de mammifères de l'Oligocène supérieur de la Limagne bourbonnaise. Annales de l'Université de Lyon, nouvelle série, 1, Science et Médecine 47: 1-327.

Waibl H., Gasse H., Constantiescu G. M., Hashimoto Y. \& Simoens P. 2005. - Nomina Anatomica Veterinaria. $5^{\text {th }}$ edition. Editorial Committee, Germany, 190 p.

WANG X. 1993. - Transformation from plantigrady to digitigrady: Functional morphology of locomotion in Hesperocyon (Canidae: Carnivora). American Museum Novitates 3069: 1-23. http://hdl. handle.net/2246/4966

White T. E. 1942. - The Lower Miocene mammal fauna of Florida. Bulletin of the Museum of Comparative Zoology 92 (1): 1-49. https://www.biodiversitylibrary.org/page/2825884

Wilson D. E. \& MitTermeier R. A. (EDS) 2009. - Handbook of the Mammals of the World. Vol. 1. Carnivores. Lynx Edicions, Barcelona, 726 p. 
Wyss A. R. \& FlynN J. J. 1993. - A phylogenetic analysis and definition of the Carnivora, in Szalay F. S., NOVACEK M. J. \& McKenna M. C. (eds), Mammal Phylogeny - Placentals. Springer Verlag, New York: 32-52.

Yensen E. \& TARIfa T. 2003. - Galictis vittata. Mammalian Species 727: 1-8. https://doi.org/10.1644/0.727.1

ZACK S. P. 2011. - New species of the rare early Eocene creodont Galecyon and the radiation of early Hyaenodontidae. Journal of Paleontology 85 (2): 315-336. https://doi.org/10.1666/10-093.1
ZACK S. P. \& RosE K. D. 2015. - The postcranial skeleton of Galecyon: evidence for morphological and locomotor diversity in early Hyaenodontidae (Mammalia, Hyaenodontida). Journal of Vertebrate Paleontology 35 (6): 1-26. https://doi.org/10.1080/0 2724634.2014.1001492

Zachos J. C., Dickens G. R. \& Zeebe R. E. 2008. - An early Cenozoic perspective on greenhouse warming and carbon-cycle dynamics. Nature 451: 279-283. https://doi.org/10.1038/ nature 06588

Submitted on 1 January 2019; accepted on 13 March 2020; published on 16 July 2020.

\section{APPENDICES}

APPENDIX 1. - Measurements, in $\mathrm{mm}$, of astragali used for the estimation of body mass. For each morphotype, only the values of the smallest and biggest specimens are provided.

\begin{tabular}{llc}
\hline Taxon/Morphotype & Specimen number & $\begin{array}{c}\text { Proximodistal } \\
\text { lenght (mm) }\end{array}$ \\
\hline Cynodictis lacustris & MNHN.F.Au1076 & 13 \\
& MNHN.F.Au847 & 15.6 \\
\hline Morphotype 1 & MNHN.F.Qu9986 & 24.8 \\
& MNHN.F.Qu10038 & 31.5 \\
\hline Morphotype 2 & MNHN.F.Qu10231 & 32.4 \\
& KUL.PLV1542.50 & 34.1 \\
\hline Morphotype 3 & MNHN.F.Qu10371 & 12 \\
\hline Morphotype 4 & MNHN.F.Qu10042 & 17.8 \\
\hline
\end{tabular}

APPENDIX 2. - Body mass (in kg and g) estimated on the basis of dental material for the amphicyonid species known in the Paleogene of Europe, with indication of their stratigraphic distribution (MP levels). Only the species with accurate stratigraphic records are considered. Estimations realized in the framework of the Brain Pioneer BR/175/PI/CARNAGES of the Federal Science Policy Office of Belgium (BELSPO).

\begin{tabular}{lcccc}
\hline & \multicolumn{2}{c}{ Bodymass } & FAD & LAD \\
\cline { 2 - 5 } Species & $\mathbf{k g}$ & $\mathbf{g}$ & (MP) & (MP) \\
\hline "Amphictis" nana & 1.15 & 1150 & 28 & 28 \\
Amphictis ambigua & 5.89 & 5890 & 28 & 28 \\
Amphictis milloquensis & 4.72 & 4720 & 29 & 29 \\
Amphictis borbonica & 3.91 & 3910 & 29 & 29 \\
Amphictis schlosseri & 5.16 & 5160 & 30 & 30 \\
Cynodictis intermedius & 6.65 & 6650 & 18 & 18 \\
Cynodictis lacustris & 5.16 & 5160 & 18 & 18 \\
"Cynodictis" compressidens & 3.79 & 3790 & 19 & 19 \\
"Cynodictis" palmidens & 8.61 & 8610 & 21 & 21 \\
Symplectocyon praecursor & 7.28 & 7280 & 21 & 21 \\
Pseudocyonopsis antiquus & 29.19 & 29190 & 21 & 23 \\
Cynodictis ferox & 8.61 & 8610 & 23 & 23 \\
Cynelos rugosidens vireti & 23.4 & 23400 & 26 & 26 \\
Brachycyon gaudryi & 45.39 & 45390 & 26 & 28 \\
Pseudocyonopsis ambiguus & 54.26 & 54260 & 26 & 28 \\
Pseudocyonopsis landesquei & 72.62 & 72620 & 26 & 29 \\
Cynelos lemanensis & 42.26 & 42260 & 27 & 30 \\
Cynelos crassidens & 24.23 & 24230 & 28 & 29 \\
Goupilictis minor & 12.77 & 12770 & 28 & 30 \\
Harpagocyon inusitatus & 35.33 & 35330 & 29 & 29 \\
Crassidia intermedia & 133.54 & 133540 & 29 & 30 \\
Haplocyon crucians & 45.39 & 45390 & 29 & 30 \\
Haplocyon dombrowskii & 40.09 & 40090 & 29 & 30 \\
Haplocyon elegans & 28.77 & 28770 & 29 & 30 \\
Ysengrinia tolosana & 95.75 & 95750 & 29 & 30 \\
Haplocyonopsis crassidens & 85.89 & 85890 & 30 & 30 \\
\hline
\end{tabular}

